Biomedical Science
Chien-Hung Chen a

T.C. $n u^{6-2}$

a Department of Internal Medicine, National Taiwan University Hospital, College of Medicine, National Taiwan University, Taipei, Taiwan; and Departments of

b Pathology,

e Oncology,

d Obstetrics and Gynecology, and

e Molecular Microbiology and Immunology, Johns Hopkins Medical Institutions, Baltimore, Md., USA

\section{Experimental Vaccine Strategies for Cancer Immunotherapy}

\begin{abstract}
Recently, cancer immunotherapy has emerged as a therapeutic option for the management of cancer patients. This is based on the fact that our immune system, once activated, is capable of developing specific immunity against neoplastic but not normal cells. Increasing evidence suggests that cellmediated immunity, particularly T-cell-mediated immunity, is important for the control of tumor cells. Several experimental vaccine strategies have been developed to enhance cell-mediated immunity against tumors. Some of these tumor vaccines have generated promising results in murine tumor systems. In addition, several phase I/II clinical trials using these vaccine strategies have shown extremely encouraging results in patients. In this review, we will discuss many of these promising cancer vaccine strategies. We will pay particular attention to the strategies employing dendritic cells, the central player for tumor vaccine development.
\end{abstract}

\section{Key Words}

Tumor immunology

Cancer

Vaccine

Immunotherapy

Antigen

Cytotoxic T lymphocyte

Dendritic cell

\section{Introduction}

\section{Immunotherapy as a Potential Alternative to Cancer} Therapy

The ideal cancer therapy should have the potency to eradicate systemic tumor at multiple sites in the body and the specificity to discriminate between neoplastic and non-neoplastic cells. In both of these respects, immunotherapy is an attractive approach. The immune system comprises a number of cell types which, when activated, are extremely efficient at killing target cells. Most importantly, the immune system is highly specific. Each of the two arms of the immune system (B cells and T cells) possesses a vast array of clonally distributed antigen receptors. The tremendous diversity of these receptors enables the immune system to recognize foreign antigens and to discriminate self from non-self.

\section{Importance of Cell-Mediated Immune Responses in Controlling Tumors}

The antitumor effects of the immune system are mainly mediated by cellular immunity. The cell-mediated component of the immune system is equipped with multiple effector mechanisms capable of eradicating tumors, and most of these antitumor immune responses are regulated by $T$ cells. Activated $T$ cells may function directly as effector cells, providing antitumor immunity through the lysis of tumor cells or through the release of cytokines capable of interfering with the propagation of tumors. Antitumor immune responses can also be achieved through the influence of T-cell-derived cytokines on other components of the immune system. Cytokines released by helper $T$ cells can alter the nature of the ensuing immune response through their effects on $T$ cell activation. Also, the function of 'non-specific' effector cells such as macro-

\begin{tabular}{ll}
\hline KARGER & (1 1998 National Science Council, ROC \\
Fax +41 61 306 12.34 & S. Karger AG, Basel \\
E-Mail karger@karger,ch & 1021-7770/98/0054-0231\$15.00/0 \\
www.karger.com & Accessible online at: \\
& http://BioMedNet.com/karger
\end{tabular}

T.-C. Wu, MD, PhD, Assoc. Prof.

Department of Patbology, Johns Hopkins University

644 Ross Building, 720 Rutland Avenue

Baltimore, MD 21205 (USA)

Tel. +14106144906 , Fax +1410614 3548,E-Mail wutc@welchlink.welch.jhu.edu 
Fig. 1. Drawing showing $\mathrm{MHC}$ molecules and antigen presentation. In general, exogenous antigens are presented through the MHC class II pathway, while endogenous antigens are presented through the MHC class I pathway. However, modified exogenous antigens can also be presented through the MHC class I pathway.

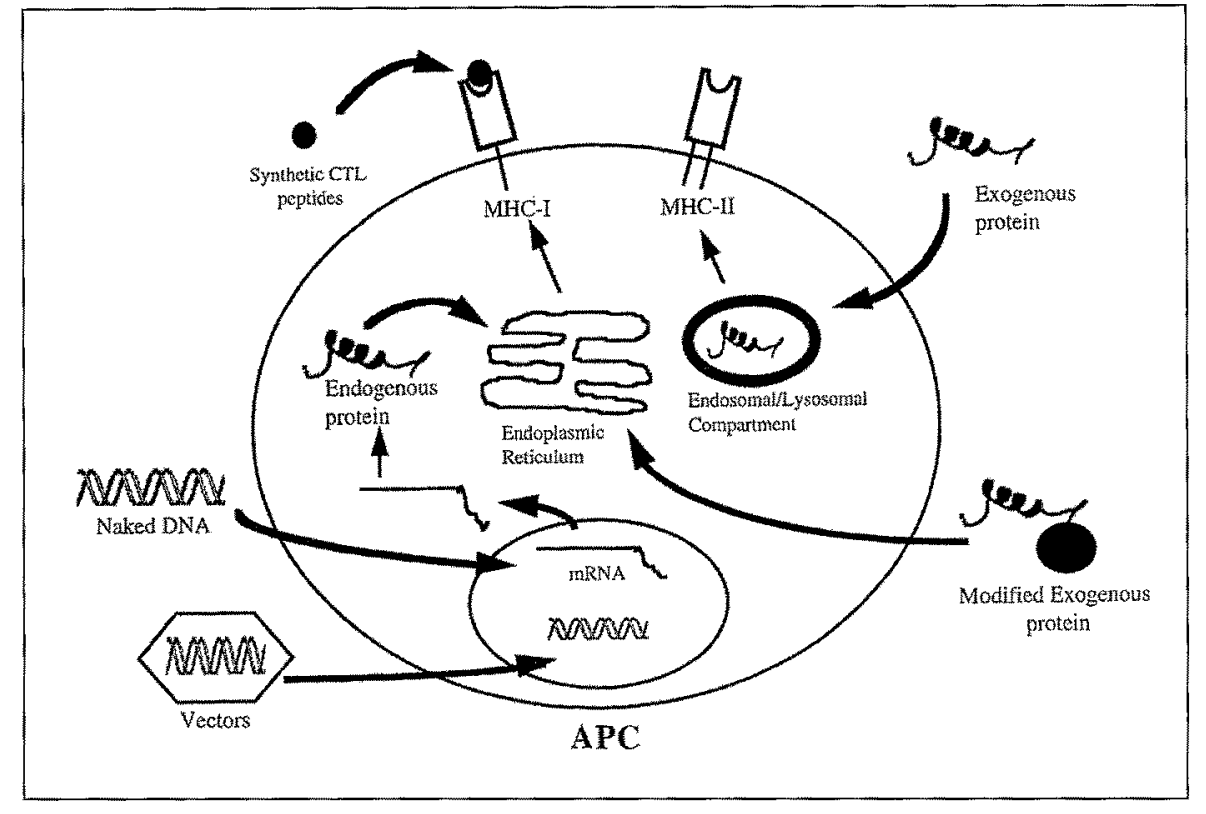

phages, natural killer cells and granulocytes are critically regulated by T-cell-derived factors. In addition to their regulatory function, $T$ cells also possess the ability to recognize tumor-specific antigens (TSAs). TSAs serve as targets which $T$ cells can use to distinguish neoplastic from non-neoplastic tissues. Therefore, T-cell-mediated immunity is one of the most crucial components of antitumor immunity.

\section{Identification of Tumor-Specific Antigen as a Prelude for the Development of Antigen-Specific Cancer Immunotherapy}

The field of cancer immunotherapy is moving toward antigen-specific vaccines based on the recognition that there are TSAs which can be identified by T cells. TSAs, when efficiently presented by antigen-presenting cells (APCs) to both CD8+ cytotoxic T lymphocytes (CTLs) and $\mathrm{CD} 4+$ helper $\mathrm{T}$ cells, are capable of inducing potent T-cell-mediated immunity - the most crucial component of antitumor immunity. There are several additional advantages of using an antigen-specific cancer vaccine. It is less likely to generate non-specific autoimmunity. It is more flexible in deciding the amount of antigen administered and the methods of antigen presentation to the immune system. It is more reproducible from patient to patient. It has the potential to correlate clinical outcome to a specific immune response [156]. Therefore, antigenspecific immunotherapy is a desirable approach for controlling tumors.
The identification of appropriate TSAs thus represents an important step in designing an effective cancer vaccine. TSAs can be classified into several categories: tumor-specific shared antigen (such as MAGE genes), differentiation antigens (such as tyrosinase), antigens resulting from mutations (such as p53 and CDK4), overexpressed antigens (such as HER-2/neu) and viral antigens, such as human papillomavirus (HPV) E6/E7 [for reviews, see ref. 170]. The list of the T-cell-defined tumor antigens grows every year. It is fair to say that every tumor cell possesses TSAs, which may be characterized already or remain to be defined in the future.

\section{Antigen Processing and Presentation - Relevance for \\ $T$ Cell Recognition of Tumor-Specific Antigens}

It is now clear that at least two distinct pathways exist for the processing of antigens recognized by $\mathrm{T}$ cells. CD8+ CTLs recognize antigens that are presented on major histocompatibility complex class I (MHC-I) molecules. MHC-I molecules are expressed on most cells of the body and carry peptide fragments of endogenously synthesized proteins. These peptide fragments are transported from the cytoplasm into the endoplasmic reticulum where they complex with newly assembled MHC-I molecules on their way to the cell surface [51]. In this way, CD8+ CTL are capable of identifying novel foreign antigens derived inside the cell. In contrast, CD4+ T helper cells identify peptide antigens that are presented on MHC class II molecules (MHC-II) predominantly expressed on specialized 
APCs such as macrophages, dendritic cells (DCs), and activated $B$ cells. For $C D 4+T$ cells to recognize complex antigenic proteins, the exogenous antigens must first be engulfed by APCs and delivered to low $\mathrm{pH}$ endosomal and lysosomal compartments containing proteases, where they are degraded into peptide fragments. The peptide fragments are further sent to the compartments of peptide loading where they bind with MHC-II molecules and are presented to CD4+ T helper cells [51]. TSAs, when efficiently presented by APCs to both CD8+CTLs and CD4+ helper $\mathrm{T}$ cells, are capable of inducing potent $\mathrm{T}$-cellmediated immunity - the most crucial component of antitumor immunity. Therefore, the ideal cancer vaccine would enhance both CD8+ CTL and CD4+ helper T cell responses by delivering a TSA into both the MHC-I and MHC-II pathways of antigen presentation (fig. 1).

\section{Dendritic Cell as a Central Player for Tumor Vaccine Development}

DCs are the most potent professional APCs that prime helper and killer $\mathrm{T}$ cells in vivo [for review, see ref. 23, 63, 145]. DCs can stimulate T cells because of their high levels of MHC-I and MHC-II molecules, costimulatory molecules like B7, and intercellular cell adhesion molecules (ICAM-1 and ICAM-3) and lymphocyte function-associated antigen-3. To effectively present antigens, DCs perform a series of coordinated tasks. Immature DCs develop from hematopoietic progenitors and are strategically located at body surfaces and in the interstitial spaces of most tissues. There, DCs are equipped to capture antigens and to produce large numbers of immunogenic MHCpeptide complexes. In the presence of maturation-inducing stimuli such as inflammatory cytokines or stimulation via $\mathrm{CD} 40$ [171], DCs upregulate adhesion and costimulatory molecules to become more potent, terminally differentiated, stimulators of $T$ cell immunity. At the same time, numerous intracellular MHC-II compartments seem to discharge MHC-II-peptide complexes to the cell surface where they can be unusually long lived $[22,115]$. DCs also migrate to secondary lymphoid organs to select and stimulate rare antigen-specific $T$ cells [7]. Thus, vaccine strategies employing DCs to enhance T-cell-mediated immunity against tumor have become extremely important.

In this review, we will focus our discussion on strategies that employ characterized TSAs. However, we will also discuss strategies aiming at controlling tumors without known TSAs since TSAs for most tumors are still undefined. Most of these strategies involve activation of $T$ cells and usage of APCs, particularly, DCs in vivo.
Table 1. Strategies for tumor vaccines

Vector-based vaccine

Viral vectors: adenovirus, vaccinia virus

Bacterial vector: $L$. monocytogenes, $S$. typhimurium

Combination of different vectors

Peptide-based vaccine

Adjuvants for peptide vaccine: cytokine, polycation, heat shock protein

Protein-based vaccine

Adjuvants for protein vaccine: cytokine, immunostimulatory $\mathrm{CpG}$ oligodeoxynucleotides

Viral-like particle, heat shock protein

DNA vaccine

Route of DNA vaccine: intramuscular, intradermal via gene gun Adjuvants for DNA vaccine: cytokine, costimulators

Cell-based vaccine

DC-based vaccine

DCs pulsed with peptide/protein

DCs transduced with genes coding for TSA

DCs transfected with naked DNA

DCs transduced with recombinant adenovirus vectors

DCs transduced with recombinant retroviruses

DCs transduced with recombinant vaccinia virus

DCs armed with the full antigenic spectrum of tumor cells DCs pulsed with unfractionated acid-eluted peptides

DCs pulsed with tumor extracts

DCs fused with tumor cells

DCs transduced with tumor-derived RNA

Tumor cell vaccines

Vaccine strategies using the GM-CSF

Autologous GM-CSF transduced cell-based vaccines Allogeneic GM-CSF transduced cell-based vaccines Bystander GM-CSF releasing microspheres or cells

Vaccine strategies using the Flt $3-\mathrm{L}$

Tumor cell vaccines enhancing $T$ cell activation Tumor cells transduced with MHC or costimulatory molecules

Tumor cells transduced with CD40 ligands

Tumor cells incubated with bispecific monoclonal Abs

Others

Releasing the inhibition by CTLA-4

Transducing the $T$ cells with chimeric receptor gene

Some of these strategies use DCs via ex vivo methods for the development of cancer vaccines. We have arbitrarily divided current cancer immunotherapeutic strategies into five categories based on the form of vaccine administered: (1) vector-based vaccines; (2) peptide-based vaccines; (3) protein-based vaccines; (4) DNA vaccines; and (5) cell-based vaccines (table 1 ).

J Biomed Sci 1998;5:231-252 


\section{Vector-Based Vaccines}

Vector-based vaccines can be used to express the TSAs, cytokines, costimulatory molecules, or combinations of these molecules, for the prevention and treatment of tumors. These vectors can be classified into the following categories: (1) viral vectors, such as adenovirus (AdV) and vaccinia virus (vV), and (2) bacterial vectors, such as $L i s$ teria monocytogenes and Salmonella typhimurium.

\section{Viral Vectors}

\section{Adenovirus Vector}

Recombinant AdV encoding TSAs can induce CTL responses and antitumor effects. Mice vaccinated with recombinant $\mathrm{AdV}$ encoding the tumor antigen $\mathrm{P} 815 \mathrm{~A}$ can induce an anti-P815A CTL response [175]. Recombinant $\mathrm{AdV}$ encoding a model tumor antigen, $\beta$-galactosidase ( $\beta$ gal), administered with exogenous interleukin-2 (IL-2), can lead to a reduction of an established $\beta$-gal-expressing CT26 murine colorectal cancer [28]. Similarly, immunization with AdV encoding melanoma-associated antigen, $\mathrm{gp} 100$, can protect mice from intradermal challenge with murine B16 melanoma cells [183]. This protection depends on both CD8+ and CD4+ T cells [183]. Since AdV has a large cloning capacity, multiple CTL epitopes can be cloned to a single $\mathrm{AdV}$. Protective antitumor immunity to multiple tumor antigens can be induced by vaccination with recombinant $\mathrm{AdV}$ encoding multiple tumor-associated CTL epitopes in a string-of-beads fashion [165]. The advantages of the AdV encoding multiple CTL epitopes derived from several TSAs are that the risk of tumor immune escape by antigen loss or antigen mutation is relatively low and it largely eliminates the risk of transformation by recombinant vector carrying functional oncogenes.

The recombinant $\mathrm{AdV}$ can also be used for active immunization without defined TSAs. This can be done by direct intratumor injection of cytokine-encoding AdV vaccines. AdV encoding cytokines such as IL-2 [68], and IL-12 [12, 19, 27] have been shown to be successful in producing the regression of established tumors [for reviews, see ref. 42]. The IL-12-expressing $A d V$ acts by activating the host immune system. Its activity is lost in nude mice and greatly inhibited by co-administration of antiCD4 or anti-CD8 antibodies (Abs). The mechanism may include direct natural killer or CTL activity as well as indirect effects of interferon- $\gamma(\operatorname{IFN}-\gamma)[12,27]$. This antitumor effect of cytokine-encoding AdV vaccines can be further enhanced by introducing costimulatory molecules along with cytokines. Intratumoral injection of $\mathrm{AdV}$ vectors encoding both IL-12 and B7-1 costimulatory molecule which act synergistically can facilitate tumor regression. The antitumor effect is higher than co-injection of two separate AdV expressing IL-12 and B7-1 [117].

The AdV is a widely used vector with several obvious advantages. It has a cloning capacity of approximate $8 \mathrm{~kb}$ in size allowing the insertion of a relatively large gene. It can be prepared easily in high titer. AdV can transduce a wide range of cell types with a remarkable transduction efficiency and does not integrate into the host genome, eliminating the safety concern of insertional mutagenesis. AdV can transduce slowly dividing tumor cells, abolishing the necessity of propagating the tumor cells in tissue cultures. The major concern of using $\mathrm{AdV}$ vaccine is the production of anti-AdV Ab by the host, which may decrease the therapeutic effect. However, Bramson et al. [13] have shown that the preexisting immunity to AdV does not prevent antitumor effect following intratumoral administration of a IL-12-expressing AdV vector.

\section{Vaccinia Virus Vector}

Vaccinia virus (vV), a member of the poxviruses family, can also be used to mediate the transfer of genes into host APCs. This strategy offers several appealing features including high efficiency of infection and high levels of recombinant gene expression [102]. Infection with recombinant $\mathrm{vV}$ and expression of the desired gene product occurs quickly. Furthermore, the vaccinia genome has abundant 'room' for accommodating large genetic insertions. The availability of replication-deficient recombinant pox virus, such as canarypox virus, has provided great opportunity to use recombinant canarypox virus as a vector for gene transfer into host APCs. First, these constructs are likely to be extremely safe, as productive viral replication is restricted to avian species so that infection of mammalian cells fails to generate infectious viral particles [116]. Second, T cell responses against vaccinia antigens (present in most of the adult population immunized against smallpox) do not significantly cross-react with canarypox antigens [53], obviating the concern that preexisting immunity would preclude immunization with canarypox virus. Finally, the chance of integration of vaccinia genome into the host genome is extremely small. These characteristics make canarypox virus or other similar $\mathrm{vV}$ suitable vectors for tumor vaccines.

Several studies have shown that antigen-specific immunotherapy using vaccinia vectors has generated strong CTL activity and antitumor effect. Mice inoculated with 
MUC1-expressing vV demonstrated MUC1-specific cytolytic responses and could prevent MUC1-expressing pulmonary metastases [2]. However, MUC1-expressing $\mathrm{vV}$ must be administered with $\mathrm{B}$ 7-expressing $\mathrm{vV}$ to treat the established MUC1-positive metastases [2]. Similarly, a double recombinant $\mathrm{vV}$ engineered to express both $\mathrm{B} 7-1$ and the model antigen $\beta$-gal was capable of significantly reducing the number of established pulmonary metastases [24]. Furthermore, administration of adjuvant IL-12 can cooperate with B7-1 to enhance the efficacy of recombinant $\mathrm{vV}$ vaccines [119]. $\mathrm{vV}$ vaccines have also been applied clinically. A recombinant $\mathrm{vV}$ encoding HPV 16 E6/E7 has been used for phase I clinical trial in cervical cancer patients [11]. Furthermore, a carcinoembryonicantigen-expressing recombinant $\mathrm{vV}$ has been used in patients with advanced colorectal cancer [98]. No significant complications or environmental spread of $\mathrm{vV}$ were noted in these trials.

Recently, vV has also been utilized to explore tumor vaccine strategies employing intracellular sorting signals. The increased understanding of intracellular pathways for antigen presentation has created the potential for designing novel strategies to enhance vaccine potency. Wu et al. [179] have previously linked the sorting signals of the lysosome-associated membrane protein-1 (LAMP-1) to HPV-16 E7 antigen, creating a chimera, Sig/E7/LAMP-1. They found that expression of this chimera in vitro and in vivo with a recombinant $\mathrm{VV}$ targeted $\mathrm{E} 7$ to endosomal and lysosomal compartments and enhanced MHC-II presentation to $\mathrm{CD} 4+\mathrm{T}$ cells compared to $\mathrm{VV}$ expressing wild type E7. Furthermore, the Sig/E7/LAMP-1 vV vaccine cured established tumors containing the $\mathrm{E} 7$ antigen in the murine model while the wild-type $\mathrm{E} 7 \mathrm{vV}$ showed no effect on this established tumor [85]. These experiments demonstrate that modifications rerouting a cytosolic TSA to the endosomal/lysosomal compartment can profoundly improve the in vivo therapeutic potency of recombinant vaccinia vaccines.

\section{Bacterial Vectors}

\section{Listeria monocytogenes}

Listeria monocytogenes has recently emerged as an exciting prospect for use as a recombinant vaccine for human cancers, based on its ability to generate both $\mathrm{CD} 8+$ and $\mathrm{CD} 4+$ immune responses and to induce regression of established tumors expressing a model antigen. $L$. monocytogenes is an intracellular bacterium that usually infects macrophages. When $L$. monocytogenes is phago- cytosed by macrophages, it is taken up in a phagosome. However, unlike other intracellular bacteria, it escapes into the cytoplasm of the macrophage by secreting a factor, listeriolysin $\mathrm{O}$, which disrupts the phagosomal membrane. Because of its presence in both endosomal compartments and cytoplasm, $L$. monocytogenes can deliver its antigens, or other foreign antigens it is carrying, to both the MHC-I and MHC-II pathways, inducing strong cellular immune responses. A recombinant L. monocytogenes secreting nucleoprotein of influenza virus has recently been shown to generate potent antitumor immunity against tumors expressing influenza nuceloprotein as a model tumor antigen [110]. Furthermore, this vaccine can be administered orally without losing its efficacy [111].

\section{Salmonella typhimurium}

Attenuated bacteria, such as mutant strains of Shigella, Escherichia coli or Salmonella, can be used to carry antigens into the APCs. Among these mutant bacteria, Salmonella have already been used as live vaccines in humans. The advantage of using Salmonella as a vector is based on its natural route of infection. After leaving intestine lumen, Salmonella migrates into lymph nodes and the spleen, where it encounters macrophages and DCs. Then the attenuated Salmonella die due to its mutation, releasing multiple copies of antigen-coding plasmid inside the phagocytes, from which the strong immune reaction can be elicited. Darji et al. [38] have shown that orally administered attenuated $S$. typhimurium carrying plasmid containing coding sequences of $\beta$-gal of $E$. coli or listeriolysin of $L$. monocytogenes can induce cytotoxic and helper $\mathrm{T}$ cells as well as strong $\mathrm{Ab}$ responses. This result suggested that it may be possible to carry any eukaryocytic expression plasmid and use Salmonella as a vaccine vector [38]. Similarly, the S. typhimurium may also be used as tumor vaccines by inserting genes coding for TSAs into the Salmonella to generate TSA-specific CTL.

\section{Combination of Different Vectors}

There are advantages and disadvantages in each vector system described above [78], and it is difficult to say which vector is the best. The ideal vector should be capable of generating strong antigen-specific immune response. In addition, it should also be non-integrating, non-replicating, non-immunosuppressive, easily engineered and genetically stable [122]. However, such vectors do not exist yet. Though there are additional viral vectors currently being investigated, strategies combining 
the existing vectors may offer advantages in certain circumstances. It has been shown that boosting with heterologous vector expressing the same tumor model antigen can result in significantly longer mouse survival than boosting with the homologous vector [72]. The poor efficacy of homologous boosting regimens with viral vectors is most likely a consequence of the induction of a strong Ab response against the vector used [72].

\section{Peptide-Based Vaccines}

The characterization of multiple CTL-defined antigenic determinants has opened the possibility of developing antigen-targeted vaccines. Vaccination with synthetic peptides corresponding to CTL epitopes can induce protective CTL-mediated immunity in a variety of model systems [for review, see ref. 99]. For example, immunization with a peptide derived from the HPV-16 E7 led to the protection against a lethal dose of HPV-16 transformed tumor cells [49] and vaccination with a peptide encompassing a CTL epitope derived from chicken ovalbumin (OVA) led to the induction of protective immunity against a thymoma transfected with $\mathrm{CDNA}$ of chicken OVA [100]. In human studies, some melanoma patients vaccinated with peptides derived from melanoma-associated antigens, such as MAGE-3 or gp 100, showed significant clinical responses $[94,129]$.

The potency of peptide-based vaccines can be further enhanced by the use of adjuvants. Cytokines are potent adjuvants for the generation of immune responses with peptide-based vaccines. For example, Rosenberg et al. [129] showed that $42 \%$ of melanoma patients who received the peptide vaccine in incomplete Freund's adjuvant (IFA) plus IL-2 had an objective clinical response, while none of the patients who received the peptide vaccine in IFA alone had any objective clinical response. Polycations, such as polylysine, can also act as adjuvants for peptide vaccines. Peptides administered with polylysine protected a significant number of animals against tumor challenge in the P815 mastocytoma system [135]. Finally, heat shock proteins have been shown to be capable of delivering noncovalently bound peptide to MHC-I molecule and induce peptide-specific CTL responses [84, 144]. Mice immunized with autologous cancer-derived heat shock protein-peptide complexes resulted in retarded progression of the primary cancer, reduced metastatic load, and prolongation of life span in several murine tumor models [159].
Although vaccination with synthetic peptides corresponding to CTL epitopes can induce protective CTL responses and effective antitumor immunity in several murine tumor model systems, not all peptides are protective. Immunization with some synthetic peptides can lead to the elimination of antitumor CTL responses. For example, vaccination with a CTL epitope derived from the human adenovirus type 5 E1 A-region (Ad5E1A234-243), which can serve as a target for tumor-eradicating CTL, enhances rather than inhibits the growth of Ad5E1Aexpressing tumors $[163,166]$. However, the same epitopes loaded onto DCs can generate protective immunity. This means that it is not the peptides per se, but rather the method of presenting the epitope to $T$ cell that determines the outcome of immunization with peptide-based vaccines [Toes et al. pers. commun.]. Thus, it is important to choose the appropriate adjuvants and route of administration for peptide-based vaccines. It is important to test the peptide-based vaccine for their immunizing or tolerizing properties in vivo before clinical use.

\section{Protein-Based Vaccines}

The application of peptide-based vaccines is limited by MHC restriction and the necessity to define the CTL epitopes. Most of the CTL epitopes of TSA remain undefined and it is difficult to use peptide-based vaccines in such situations. In addition, it is too laborious to use peptide-based vaccines on a large scale. These limitations potentially can be overcome by using protein-based vaccines. Protein-based vaccines can present all possible epitopes of a protein to the immune system, thus, bypassing the MHC restriction. Furthermore, with a protein vaccine, dangerous side effects such as transformation, a potential concern with the use of recombinant viruses and DNA vaccines, are not an issue.

A growing number of modified exogenous protein antigens have been shown to be capable of generating MHC-I restricted CTL responses [for review, see ref. 76] (fig. 1). Association of exogenous antigens with some adjuvants, such as immune-stimulating complexes [158], liposomes [33], saponin [178] or squalene [120], enhances their immunogenicity for CTL precursors. Several reports have described CTL priming by injection of large, particulate antigens such as denatured aggregates [133], antigen-coupled beads [80] and virus-like particles [55, 113]. Modification of proteins with lipid conjugation converts them into potent inducers for priming CTL activities [41]. Finally, CTL responses can be efficiently generated by the 
injection of protein antigen fused with heat shock proteins [152].

The exact mechanisms by which modified exogenous antigens are presented through the MHC-I pathway (cross-priming) remains to be elucidated. There is no general consensus as to the cellular mechanism of antigen transfer in these experiments. Initial studies suggested that MHC-I presentation of exogenous antigens occurs by regurgitation of peptides generated in the phagosomal compartment to the cell exterior followed by binding to empty MHC-I molecules [61]. Another set of studies suggested a phagosome to cytosol transfer of antigens with ultimate cytosolic processing and TAP-dependent transport of peptides into the endoplasmic reticulum for binding to nascent MHC-I molecules [182]. The various proposed pathways for antigen presentation were distinguishable in that the first model proposed a TAP-independent pathway for MHC-I processing of exogenous antigens, whereas the later model proposed a pathway which was TAP dependent. It is possible that both cellular mechanisms are accurate but are dependent on the exact modification and type of exogenous antigens used.

Several protein-based vaccines have been shown to generate protective antitumor effects in murine models $[40,55,62,113,152]$. For example, immunization with soluble whole HPV-16 E7 protein in IFA rendered mice insensitive to a subsequent challenge with HPV-16-transformed tumor cells in vivo [40]. Chimeric HPV virus-like particles consisting of the $\mathrm{L} 1$ major capsid protein plus the entire E7 fused to the L2 minor capsid protein are capable of protecting the mice from tumor challenge with E7-expressing tumor cells, even in the absence of adjuvant $[55,113]$. Suzue et al. [152] demonstrated that the injection of an hsp70-OVA fusion protein can stimulate the production of CD8+CTL that recognize the immune dominant OVA octapeptide and protect mice against the lethal challenge with OVA-expressing melanoma cells.

There are several strategies to increase the potency of protein-based vaccines. Granulocyte macrophage-colony stimulating factor (GM-CSF) fused to TSAs has been shown to enhance the potency of protein-based vaccines. If dendritic and/or other GM-CSF-responsive cells are the critical APCs in generating enhanced immune responses, then linkage of an antigen to GM-CSF molecule in a chimeric vaccine may enhance the targeting of the antigen into the endocytic compartment of these cells after the chimeric molecule has bound to the GM-CSF receptor. Tao et al. [160] have shown that the immunogenicity of idiotype (Id; the variable region of the immunoglobulin molecule expressed on malignant $B$ cells) can be dramati- cally increased by fusing tumor Id to GM-CSF. The chimeric Id-GM-CSF was capable of protecting recipient animals from challenge with an otherwise lethal dose of tumor cells $[29,160]$. These studies indicate that GMCSF linked to an antigen can significantly enhance the immunogenicity of the antigen. Immunostimulatory $\mathrm{CpG}$ oligodeoxynucleotides (ODN) that contain unmethylated CpG motifs have been shown to be capable of enhancing the potency of protein vaccines by inducing macrophages to secrete IL-12 and shift the cytokine profiles to $T$ helper type 1 immunity [31, 125]. Using the murine $38 \mathrm{C} 13 \mathrm{~B}$ cell lymphoma model, Weiner et al. [176] have demonstrated that $\mathrm{CpG}$ ODN can function as immune adjuvants in tumor antigen immunization. Mice immunized with $\mathrm{CpG}$ ODN as an adjuvant were protected from tumor challenge to a degree similar to that seen in mice immunized with complete Freund's adjuvant in the murine lymphoma model [176]. The benefit of using CpG ODN instead of complete Freund's adjuvant is its lack of significant toxicity, and therefore $\mathrm{CpG}$ ODN can potentially be applied clinically.

\section{DNA Vaccines}

The use of naked DNA for vaccination has the clear advantages of purity, simplicity of preparation, and stability. In addition, DNA-based vaccines can be prepared inexpensively and rapidly on a large scale. DNA-based vaccines have the advantage over peptide vaccines in that their MHC-peptide complexes are expressed for longer periods of time, which may be vital given the relatively short half-life of MHC I-peptide complexes on APCs. Furthermore, the MHC restriction of peptide-based vaccines may be bypassed with approaches that directly transduce DNA coding for TSAs inside APCs so that the peptides can be presented by the patient's own MHC molecules. These advantages support enthusiastic interest in the development of vaccines employing naked DNA.

DNA vaccines can be administered to the host by intramuscular injection, intradermal injection via hypodermic needle or via gene gun (a ballistic device for delivering DNA-coated gold particles into the epidermis), intravenous injection, and intranasal delivery [for reviews, see ref. 45,124$]$. Intramuscular and intradermal injection via gene gun have been shown to induce potent immune response and antitumor immunity. Mice intramuscularly injected with the naked plasmid DNA encoding SV40 T antigen have elicited CTL activity specific for SV40 $\mathrm{T}$ antigen [15] and generated protective immunity 
against a lethal challenge with syngeneic SV40-transformed cells $[15,134]$. Similarly, mice intramuscularly immunized with the free human chorionic gonadotropin$\beta$ (hCG- $\beta$ ) expression construct developed a strong CTL response against hCG- $\beta$ and demonstrated a marked reduction of tumor size of syngeneic SP2/O myeloma cell line that constitutively expresses the free hCG- $\beta$ protein [50]. Similar results were observed in mice immunized with DNA constructs encoding the Id [153], P815A TSA [127] and human carcinoembryonic antigen [35]. DNA vaccinations using the gene gun method are capable of generating effective antitumor immunity in several murine tumor models. For example, mice immunized with a minigene coding for a single epitope derived from mutant p53 can induce tumor protective CTL activities [32]. In addition, mice immunized with lacZ-containing plasmid can prevent the growth of pulmonary metastases of the $\beta$-gal-expressing murine colorectal cancer [73].

The information about the mechanisms of DNA vaccination by intramuscular injection or gene gun delivery is accumulating. Following intramuscular injection, some of the myocytes are transfected by the DNA vaccines, and the transfected myocytes produce protein and transfer the antigens to the bone-marrow-derived professional APC [161]. Alternatively, the injected DNA may move as free DNA through blood to the spleen where professional APCs initiate responses [124]. Following gene gun delivery, the epidermal Langerhans cells are transfected by the DNA vaccine and then serve as APCs. The DCs of the skin carry the antigens from the skin to the draining lymph nodes, where the antigen-loaded DCs activate the naive T cells [34]. The method of DNA inoculation (gene gun vs. intramuscular injection) and the form of the DNA-expressed antigen (cell-associated vs. secreted) determine whether T-cell help will be primarily type 1 or type 2 [for review see ref. 124].

Several methods employing cytokines and costimulatory molecules have been shown to enhance the potency of DNA vaccines [36, 73]. Irvine et al. [73] showed DNA immunization with $\beta$-gal-containing plasmid alone had little or no impact on the growth of established lung metastases of tumors expressing $\beta$-gal. Interestingly, significant reduction in the number of established lung metastases was observed when cytokines, especially mouse rIL-12, were given after DNA inoculation [73]. The magnitude and nature of the immune response to a DNA vaccine can be differentially regulated by codelivery of various mouse cytokine genes. The CTL activity and antitumor effect induced by DNA vaccination was most significantly enhanced by codelivery of the IL- 12 or IFN- $\gamma$ gene, whereas codelivery of the IL-4 gene suppressed the activity [30]. The cytokine gene can be fused with the TSA gene to generate a chimeric gene and administered as a single DNA vaccine. Immunization with DNA constructs encoding the Id of a murine B-cell lymphoma induced specific anti-Id antibody responses and protected mice against tumor challenge. Vaccination with DNA encoding an Id/GM-CSF fusion protein improved vaccine efficacy [153]. The potency of DNA vaccines can be increased by costimulatory molecules. It is well known that costimulators are required to generate a CTL response. DNA vaccination with an OVA-encoding plasmid plus B7-1-encoding plasmid, but not B7-2-encoding plasmid, prolonged survival in mice challenged with an OVA-transfected tumor [36]. These results suggest the antitumor effect of DNA vaccine can be enhanced by co-administration of cytokines, gene encoding cytokines or B7-1 molecules.

DNA vaccines can also be used in tumors without defined TSAs. This is done by directly injecting the DNA plasmid encoding the cytokine genes into mice carrying tumors. Sun et al. [151] showed that gene gun delivery of cytokine (IL-6, IL-2, IFN- $\gamma$ or tumor necrosis factor- $\alpha$, $\mathrm{TNF} \alpha$ ) encoding plasmids into the epidermis or dermis overlying established murine tumors can lead to the regression of these tumors. Among different cytokines tested, vaccination with DNA encoding IL-12 generated the most potent antitumor effect in mice [118]. Using a metastatic murine tumor model, P815, Rakhmilevich et al. [118] showed that a delivery of IL-12 cDNA into the skin overlying an advanced intradermal tumor, followed by tumor excision and three additional IL-12 gene transfections, could significantly inhibit systemic metastases, resulting in extended survival of the mice.

\section{Cell-Based Vaccine}

Cell-based vaccines for cancer immunotherapy can be arbitrarily divided into two broad categories: DC based vaccines and cytokine-transduced tumor-cell-based vaccines. DCs are the most potent professional APCs that are specialized to prime helper and killer $\mathrm{T}$ cells in vivo. Therefore, vaccine strategies employing DCs generated ex vivo to enhance T-cell-mediated immunity against tumors have become a desirable option. The understanding that DCs can be generated from hematopoietic progenitors in the setting of various cytokines, mainly GM-CSF and Flt3-ligand (Flt3-L), has created an opportunity to use a tumor-cell-based vaccine transduced with GM-CSF or Flt3-L cytokines to expand and prime DCs in vivo. 
Such an approach will be very suitable for those tumors without known TSAs.

\section{Dendritic Cell-Based Vaccines}

\section{Generation of Dendritic Cells ex vivo}

For years it has remained difficult to generate large numbers of DCs because little was known about DC maturation and the lineage-specific markers which define their cellular differentiation state. Recently, new advances have been made in understanding not only the origin of DCs and their antigen uptake mechanisms but also the signals that stimulate their migration and maturation into immunostimulatory APCs [for recent review, see ref. $23,63]$.

These advances in DC biology have contributed to the development of several different methods to generate large numbers of active DCs ex vivo. The methods have been derived from the realization that the cytokines, GMCSF and Flt3-L are critical factors in inducing the differentiation of primitive hematopoietic precursors into DCs as a lineage distinct from macrophages and granulocytes $[65,70,71,87,88,177]$. DCs can be generated from either proliferating $\mathrm{CD} 34+$ or from nonproliferating CD14+ progenitors. CD34+ cells are present in bone marrow, in cord blood, and in adult blood, and each can serve as a source of progenitors for DCs. Under GM-CSF and TNF$\alpha, \mathrm{CD} 34+$ hematopoietic progenitors develop into functional DCs $[20,21,64,126,140,149,150,155]$. Similarly, CD14+ blood monocytes can differentiate into functionally mature DCs under the function of GM-CSF and IL-4 cytokines [9, 132, 184]. Recently, Flt3-L has been noted to have a growth-stimulatory effect on DCs [93, 139]. Flt3-L in cooperation with TGF- $\beta 1$ potentiates in vitro development of DCs and allows single-cell DC cluster formation under serum-free conditions [147]. More recently, morphologically equivalent DCs have been generated in serum-free media. This method avoids the undesirable clinical risks of allergic reaction or simulation of immune responses against unintended antigens [101]. The DCs derived from culturing hematopoietic progenitors appear to have similar APC function as purified mature DCs. Therefore, DCs generated ex vivo provide a source of professional APCs for use in experimental immunotherapeutics.

Immortalized DC lines have recently become available. Paglia et al. [109] generated an immortalized murine DC line utilizing a retrovirally delivered env-myc fusion gene into primary murine splenic cultures. The cloned
DCs exhibited the ability to process and present antigen in vitro as well as to sensitize $\mathrm{T}$ lymphocytes in vivo. Recently, Shen et al. [138] transduced GM-CSF into murine bone marrow cultures followed by supertransfection with myc and rafoncogenes. They successfully generated an immortalized clone which displayed dendritic morphology, DC-specific markers, and high levels of MHC-I and MHC-II molecules and costimulatory molecules. These immortalized DCs represent a very important reagent for testing various tumor vaccine strategies that use DCs.

Vaccine Strategies using the Dendritic Cells Generated exvivo

The availability of large quantities of active DCs generated ex vivo has created the opportunity to test various vaccine strategies employing DCs for immunotherapy. There are several vaccine strategies using DCs prepared with known TSAs such as HPV-16 E6/E7 or with undefined tumor antigens. Vaccine strategies using the DCs generated ex vivo can be classified as follows: (1) DC pulsed with peptides/proteins; (2) DC transduced with genes encoding TSAs through naked DNA or viral vectors, and (3) DCs armed with the full antigenic spectrum of tumor cells (for those tumors with uncharacterized TSAs). The various vaccine strategies are summarized in figure 2.

Dendritic Cells Pulsed with Peptides/Proteins

Presentation of peptides derived from TSAs to the immune system by DCs is a promising method of circumventing tumor-mediated immunosuppression. DCs pulsed with tumor-specific $T$ cell epitopes can generate protective antitumor $\mathrm{T}$ cell-mediated immunity. Treatment of tumors with peptide-pulsed DCs has resulted in sustained tumor regression in several different tumor models [for review, see ref. 97]. For example, Mayordomo et al. [96] demonstrated in murine tumor models that bone-marrow-derived DCs pulsed ex vivo with synthetic HPV-16 E7 peptide (aa 49-57) serve as an effective antitumor vaccine, protecting animals against an otherwise lethal tumor challenge. Furthermore, peptide-pulsed DCs have been used in patients with prostate cancers and found to be effective in generating cell-mediated immune responses [103, 162]. Clinical response can also be detected in melanoma patients immunized with autologous DCs pulsed with MAGE-1 or MAGE-3 peptides [106]. The identification of MHC-I and MHC-II epitopes of TSAs can facilitate the application of DC pulsed with peptides.

J Biomed Sci 1998;5:231-252 
Fig. 2. Drawing showing the various vaccine strategies using DCs generated ex vivo. The details of these vaccine designs are discussed in the text.

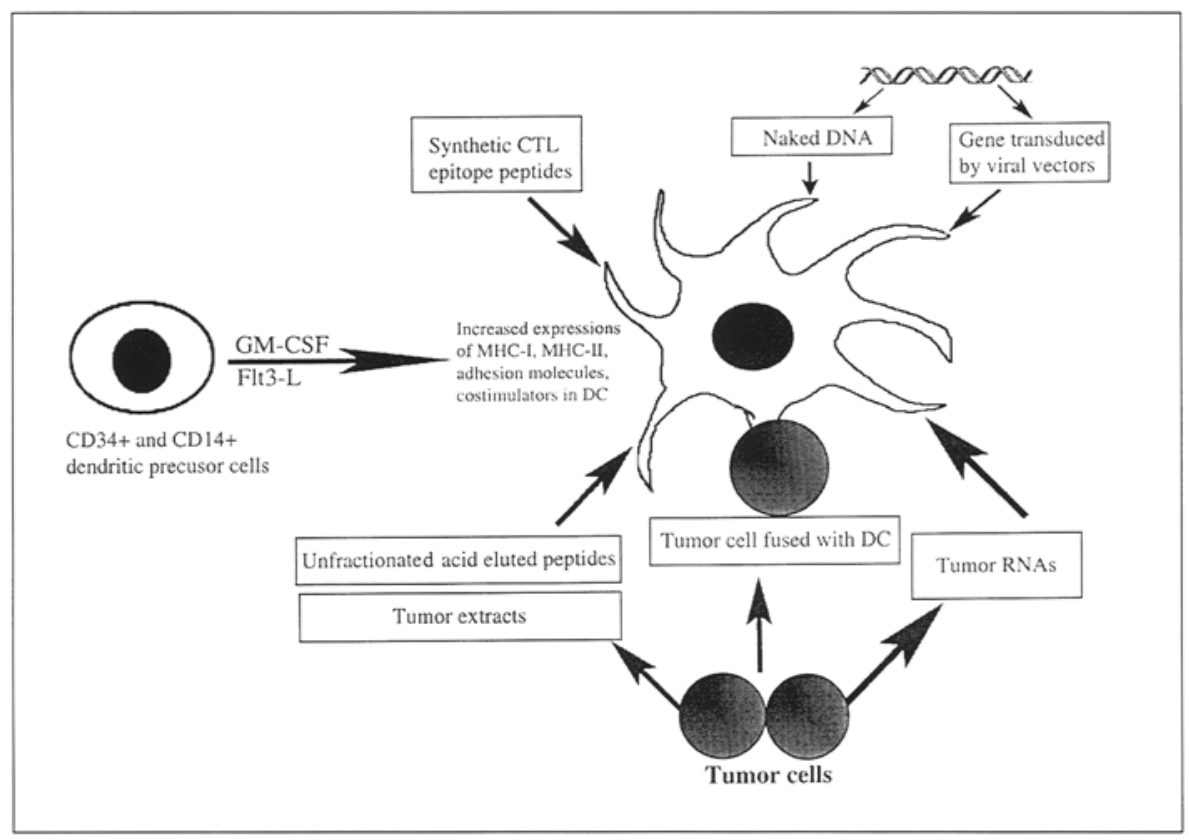

DCs pulsed with proteins can also generate effective antitumor immunity [108]. For example, Hsu et al. [66] investigated the ability of autologous DCs pulsed ex vivo with tumor-specific Id protein to stimulate host antitumor immunity. They have observed that all their patients develop measurable antitumor cellular immune response. Furthermore, significant clinical responses have been observed in some of their patients [66]. Similarly, De Bruijn et al. [40] showed DCs pulsed with HPV-16 E7 protein are not only recognized in vitro by E7-specific CTLs but also elicit E7-specific CTL responses in vivo, associated with protection against a challenge with syngeneic HPV16-induced tumor cells.

\section{Dendritic Cells Transduced with Genes Coding for}

Tumor-Specific Antigens

The MHC restriction of peptide-based vaccines may be bypassed with approaches that directly transduce genes coding for TSAs inside the DCs so that the peptides can be presented by any given patient's HLA molecules. Gene transfer into DCs can be accomplished by a variety of methods involving either naked DNA or the use of viral vectors.

Dendritic Cells Transfected with Naked DNA. The major limitation to naked DNA gene transfer into the DCs is poor transfection efficiency by various physical methods [4]. However, several groups have improved the poor transfection efficiency in DCs. Rouse et al. [131] have used the cationic lipid, DOTAP, to form a complex with the DNA to enhance the efficiency of transfecting naked DNA into the DCs. DCs transfected with DOTAP-complexed DNA induced a strong CTL response, which was superior to the CTL response induced by similarly transfected macrophages [131]. Tuting et al. [168] have used particle-mediated transfer of genes encoding TSAs to generate DCs expressing tumor peptide-MHC complexes. Bone-marrow-derived DCs were transfected with plasmid DNA encoding HPV-16 E7 ex vivo, and they applied the transfected DCs as a vaccine in mice. The method is unique in that the plasmid DNA was precipitated onto gold particles which were loaded into a helium pulse gun (gene gun) and used to bombard DCs evently spread onto the bottom of a pre-wetted well. Not only did the vaccine successfully generate an antigen-specific CTL response in vivo, but it also promoted the rejection of a subsequent, normally lethal challenge with an HPV-16 transformed tumor cell line [168].

Dendritic Cells Transduced with Recombinant Adenovirus Vectors. The efficiency of gene transfer by the recombinant $A d V$ vector has been shown to be superior to the naked plasmid DNA transfection approach [4]. Wan et al. [173] showed that up to $90 \%$ of the murine bonemarrow-derived DCs could be infected with an AdV vector expressing the $\beta$-gal gene. The physiologic and phenotypic characteristics of the DCs were unchanged when infected with the AdV vector [173]. The efficiency of 
AdV-mediated gene transfer into DCs can be further enhanced by cationic liposomes [43]. In one study, the expression of the gene transduced was detectable in the spleen for at least 3 days following intravenous injection of Ad-transduced DCs [173]. The efficiency of AdVinfected DCs in eliciting a specific CTL response was reported to be superior to that of a DC infected with recombinant $\mathrm{vV}$ or pulsed with peptide or protein [17]. The benefits of vaccine strategies using DCs transduced with genes via $\mathrm{AdV}$ vectors were clearly demonstrated in several studies using various model antigens including $\beta$ gal [173], chicken OVA [17], and the human MART-1/ Melan-A melanoma antigen [123]. These studies have shown that antigen-specific CTL activities and protective antitumor immunity were generated in mice vaccinated with DCs transduced with genes via AdV vectors. Furthermore, AdV-mediated gene transfer into DCs generated a therapeutic response to preestablished tumors $[142,173]$.

When AdV-mediated gene transfer into DCs is compared to direct immunization of mice with recombinant $\mathrm{AdV}$, the former avoids the disadvantage of stimulating the production of neutralizing Abs which is almost always seen in direct immunization with virus vectors [17]. Direct immunization of mice with recombinant $\mathrm{AdV}$ resulted in the induction of high titers of neutralizing Abs, which precluded a boost of a CTL response after repeated inoculations. However, repeated injections of virus-infected DCs induced only low titers of neutralizing Abs [17]. In addition, the presence of neutralizing Abs specific for the virus did not affect the usefulness of infected DCs as repeated applications of virus-infected DCs boosted the CTL response even in mice previously infected with the recombinant vector [17].

Dendritic Cells Transduced with Recombinant Retroviruses. The major limitation of $\mathrm{AdV}$ for gene transfer is that the transfected DNA does not integrate into the genome of the transduced cell and thus, expression is lost after 1-4 weeks. Retroviruses, on the other hand, can infect and integrate into the host genome, a critical requirement for efficient gene transfer and for the establishment of stable expression. Highly efficient retroviral vectors have recently become available for gene transfer [46]. The use of these high-efficiency retroviral vectors to carry TSA genes into DCs has a number of specific advantages. The transduction is rapid and selection is unnecessary. In addition, the absence of selection avoids the potential problem that selected subclones may display an altered physiology as compared to the original DC population. Several studies have shown that gene transfer in murine and human DCs using retroviruses is a feasible strategy, reporting between 11.5 and $72 \%$ of the DCs expressing the specific genes transferred $[1,121,143$, 154]. In addition, retrovirally transduced DCs maintain their functional properties, stimulating allogeneic $T$ cells with similar efficiency as non-transduced DCs $[8,154]$. More recently, retrovirally transduced DCs have been shown to be capable of generating antigen-specific CTL activities and protective antitumor immunity in murine models [121, 143]. For example, Specht et al. [143] reported that lac-Z-transduced DCs significantly reduced the number of lung metastases using the $\beta$-gal-expressing murine model tumor, CT26.CL25. In addition, the $\beta$-galspecific CTL activities generated in mice vaccinated with lac-Z-transduced DCs were significantly higher than CTL activities generated from mice immunized with DCs pulsed with $\beta$-gal peptide [143].

Dendritic Cells Transduced with Recombinant Vaccinia Virus. $\mathrm{vV}$ can also be used to mediate the transfer of genes into DCs. This gene transfer strategy offers several appealing features including high efficiency of infection, and high levels of recombinant gene expression. Infection with recombinant $\mathrm{vV}$ and the expression of the desired gene product occurs quickly, minimizing the period of DC culture that is required before immunization. More recently, DCs transduced with recombinant $\mathrm{vV}$ have been shown to be capable of generating antigen-specific CTL activities $[16,79]$. Specifically, Bronte et al. [16] demonstrated that murine DCs infected with a lac-Z recombinant $\mathrm{vV}$ express $\beta$-gal and generate a $\beta$-gal-specific CTL response. They also showed that DCs express $\beta$-gal only under the control of the early promoters of $\mathrm{vV}$ even though late promoters were intrinsically more active in cell types other than DCs. Kim et al. [79] also found that human DCs infected with a recombinant poxvirus encoding melanoma-associated antigen gene, MART-1, induced MART-1-specific CTL responses in melanoma patients. These data highlight the potential of DCs transduced with recombinant $\mathrm{vV}$ for use in vaccine development.

In summary, when genetically modified DCs expressing TSAs are used as vaccines, antitumor killer cells are generated and antitumor effects are observed.

\section{Dendritic Cells Armed with the Full Antigenic}

Spectrum of Tumor Cells

Even with the promise that DCs pulsed with peptides/ proteins and gene transduced with TSAs have shown in tumor models, there are several limitations. The main limitation is that, for most cancers, the TSAs and T cell epitopes have not yet been characterized. An evolving 
goal of tumor immunology is to develop vaccines that will enable the body's immune system to recognize the whole spectrum of TSAs. Even though in cases in which a TSA is known such as HPV-associated neoplasm, it is reasonable to pursue vaccine strategies that arm the DCs with the full antigenic spectrum of tumor cells because the full antigenic spectrum may prove to be more immunogenic than simply using one or two TSAs. Several strategies have been developed using the DCs generated ex vivo. They can be classified as the following: (1) DCs pulsed with unfractionated acid-eluted peptides, (2) DCs pulsed with tumor extracts, (3) DCs fused with tumor cells and (4) DCs transduced with tumor-derived RNA.

Dendritic Cells Pulsed with Unfractionated Acid-Eluted Peptides. Using DCs pulsed with unfractionated acideluted tumor peptides is an option for bypassing the need of identifying TSAs. A modified acid elution method has been used to isolate epitopes from MHC-I complexes expressed at the cell surface of viable cells [146]. Recently, Zitvogel et al. [185] used DCs pulsed with unfractionated acid-eluted tumor peptides to treat mice bearing spontaneous, established tumors. They showed that the adoptive transfer of unfractionated tumor peptide-pulsed DCs dramatically suppressed the growth of weakly immunogenic tumors in MCA205 (H-2b) and TS/A (H-2d) tumor models. They also observed a marked up-regulation of IL-4 and IFN- $\gamma$ production in tumor-bearing mice immunized with DCs pulsed with tumor-eluted peptides [185]. Thus, DCs pulsed with acid-eluted peptides derived from autologous tumors represent a potential approach to treat established, weakly immunogenic tumors.

Dendritic Cells Pulsed with Tumor Extracts. Vaccination with tumor extracts is another approach that has been recently described as a method for circumventing the need to identify TSAs. The technique involves sonicating tumor cells, combining the tumor extracts with the cationic lipid DOTAP, and adding the mixture to DCs generated ex vivo [6]. Immunization of mice with DC pulsed with tumor extracts has been proven to generate tumor-specific CTL responses in poorly immunogenic murine tumor models $[6,104,105,180]$. Ashley et al. [6] also demonstrated that DC-tumor extract pulsed vaccines prolonged the survival of mice with preestablished tumors to the same extent as GM-CSF gene modified tumor vaccines [6]. The DC-tumor extract pulsed vaccine has also been shown to actually induce a cure in at least $40 \%$ of the animals injected with the murine bladder tumor (MBT-2) [105] and to cause a significant reduction in lung metastases in the B16 melanoma lung metastasis model $[105,180]$. In addition to tumor extracts, irradiated tumor cells can also be mixed with DCs and used as vaccines. In one study, DCs mixed with irradiated tumor cells inhibited the growth of primary breast cancer in a murine breast carcinoma (4T1) model [37]. However, the potential concern in using the DC pulsed tumor extracts or mixed with irradiated tumor cells in humans is the fear that they may contain some normal antigens and may possibly induce autoimmunity [6].

Dendritic Cells Fused with Tumor Cells. Another vaccine strategy that avoids the need to identify TSAs is to use DCs fused with tumor cells as vaccines. In the past, when DCs were not readily available, activated $B$ cells have been fused with tumor cells and used as tumor vaccines. Guo et al. [58] have successfully fused BERH-2 rat hepatocellular carcinoma cells with activated $B$ cells and used the hybrid cell as a vaccine in syngeneic rats, which resulted in substantial protective and therapeutic responses. Recently, it has been shown that murine hybrid cell lines produced by the fusion of DCs and a tumor cell preserve the DC phenotypes [14, 54]. Gong et al. [54] have fused DCs with murine MC38 adenocarcinoma cells. The fusion cells were positive for MHC-I and MHCII, costimulatory molecules and ICAM-1. The fusion cells stimulated naive $T$ cells in the primary mixed lymphocyte reaction and induce MC38 tumor-specific CTLs in vivo. Furthermore, immunization with the fusion cells induces the rejection of established metastases [54]. These findings suggest that the fusion of DCs and tumor cells can potentially be used in the control of tumors.

Dendritic Cells Pulsed with Tumor-Derived RNA. DCs pulsed with tumor-derived RNA have recently emerged as an effective way to induce CTL and tumor immunity. DCs pulsed with in vitro synthesized chicken OVA RNA were more effective than OVA peptide-pulsed DCs in stimulating primary, OVA-specific CTL responses in vitro [10]. In another report, mice vaccinated with DCs pulsed with B-16 total RNA generated specific CTLs against B-16 tumor cells [6]. In addition, these mice revealed a dramatic reduction in lung metastases in a highly metastatic, B16/F10.9 tumor model [10]. Furthermore, using the B-16 murine melanoma as a model for CNS tumor, Ashley et al. [6] demonstrated that DCs pulsed with unfractionated B16 total RNA can lead to prolonged survival in mice with tumor cells placed in the CNS before the initiation of vaccine therapy.

DCs pulsed with tumor-derived RNA have several advantages over the strategies using DCs pulsed with unfractionated tumor derived peptides/proteins or using DCs fused with tumor. Both DCs pulsed with unfractionated tumor derived peptides/proteins and DCs fused with 
Fig. 3. Drawing showing the various vaccine strategies of expanding and priming $D C s$ in vivo. The details of these vaccine designs are discussed in the text.

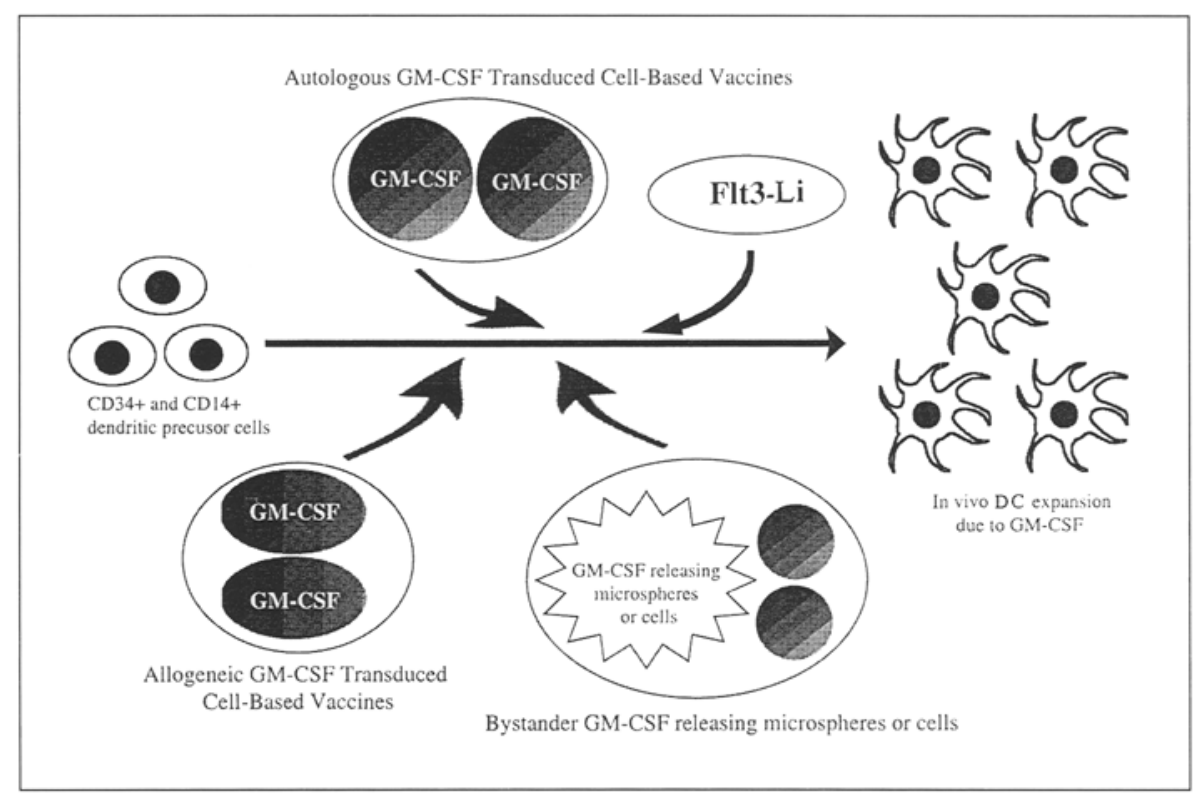

tumor require substantial amount of viable tumor cells or tumor tissue. This requirement can be difficult for patients with very small amount of tumors. The tumorderived RNA-pulsed DC-based vaccines are potentially suitable for patients bearing very small, possibly microscopic, tumors. Since cDNA can be easily generated from a very small amount of tumor cells and RNA can be further transcribed in vitro from cDNA cloned in a bacterial plasmid. It is possible to amplify the antigenic content through RNA from a small number of tumor cells. Boczkowski et al. [10] have shown that RNA generated using this approach can be highly effective in sensitizing DCs against tumors. Furthermore, tumor specific RNA can be enriched by subtractive hybridization with RNA from normal tissue, and transfected RNA may serve as a continuous source for the generation of antigenic peptides [10]. All these features have made DCs pulsed with tumor-derived RNA a desirable approach in tumor vaccine development.

\section{Tumor-Cell-Based Vaccines}

All of the methods discussed thus far involved ex vivo methods to enrich and prime DCs with tumor antigens before giving these DCs as vaccines to hosts. This section will highlight vaccine strategies that increase the numbers and function of DCs in vivo. As discussed previously, DCs can be generated from hematopoietic progenitors in the setting of various cytokines, mainly GM-CSF and Flt3-L. Instead of generating potent DCs ex vivo and injecting the cells back into a patient as a cancer vaccine, an alternative strategy is to use a vaccine with GM-CSF or Flt3-L cytokines to expand and prime DCs in vivo. Such vaccine strategies can be classified as the following: (1) autologous GM-CSF transduced cell-based vaccines, (2) allogeneic GM-CSF transduced cell-based vaccines, (3) bystander GM-CSF-releasing microspheres or cells and (4) strategies related to Flt3-L. These vaccine strategies are summarized in figure 3 .

\section{Autologous GM-CSF Transduced Cell-Based Vaccines}

GM-CSF as the Most Potent Cytokine in Cytokine-

Transduced Cell-Based Vaccines

The initial development of cytokines for cancer immunotherapy involved systemic administration of pharmacologic doses of recombinant cytokines [128]. However, this approach failed to account for a major principle in lymphokine physiology, namely that lymphokines maintain the specificity of immunologic responses partially through their paracrine function. In the past several years, there has been intense interest in the study of immune responses generated by tumor cells engineered to secrete various cytokines. This strategy seeks to alter the local immunological environment of the tumor cell so as to either enhance the antigen presentation of TSAs to the immune system or to enhance the activation of tumorspecific lymphocytes. The important concept underlying 
the use of cytokine gene-transduced tumor cells is that the cytokine is produced at very high concentrations local to the injected tumor cells. Systemic concentrations are generally quite low. This paracrine physiology much more closely mimics the natural biology of cytokine action than does the systemic administration of recombinant cytokines. Numerous reports have analyzed biological effects of injections of tumors transduced with multiple different cytokine genes [for review, see ref. 75].

Because of the wide range of local inflammatory and vaccine effects of cytokine-secreting tumors, as well as other parameters affecting experimental outcome, it is critical that these cytokines be compared for efficacy. The first study that directly compared the efficacy of multiple cytokines and other genes in murine tumor models used a highly transmissible replication-defective retroviral vector. This study demonstrated that, in a number of poorly and moderately immunogenic tumors, immunization with GM-CSF transduced tumors produced the greatest degree of systemic immunity [46]. Immunity was dependent on both CD4+ and CD8+ T cells. The potency of the effect of GM-CSF locally may be related to its unique ability in promoting the differentiation of hematopoietic precursors into DCs.

\section{Clinical Trial using Autologous GM-CSF Transduced}

Cell-Based Vaccines

The success of autologous GM-CSF transduced tumor vaccines in the murine model has prompted the design of several clinical trials of human patients with renal cell carcinoma [141], sarcoma [92] and melanoma [47, 92]. A phase I clinical trial was performed at the Johns Hopkins Medical Institutions to evaluate the safety and the induction of immune responses of a GM-CSF transduced renal cell carcinoma $(\mathrm{RCC})$ vaccine in patients with metastatic RCC. Patients with stage IIIb and IV RCC were treated in a randomized, double-blind, dose-escalation study with equivalent doses of autologous, irradiated RCC vaccine cells with or without ex vivo human GM-CSF gene transfer. The replication-defective retroviral vector MFG was used for GM-CSF gene transfer [46]. In all fully evaluable patients, no dose-limiting toxicities were encountered. Furthermore, no evidence of autoimmune disease was observed. Biopsies of intradermal sites of injection with GM-CSF gene-transduced vaccines revealed distinctive macrophage, DC, eosinophil, neutrophil, and T-cell infiltrates similar to those observed in preclinical models [141]. More interestingly, a significant clinical response was observed in a patient treated with GM-CSF genetransduced vaccine who displayed the largest delayed- type hypersensitivity conversion. No replication-competent retrovirus was detected in vaccinated patients. This phase I study demonstrated the feasibility, safety, and bioactivity of an autologous GM-CSF gene-transduced tumor vaccine for RCC patients [141].

Although the autologous GM-CSF transduced tumorcell-based vaccines have generated tremendous interest, there are several limitations of autologous tumor-cellbased vaccines [75]. The limitations mainly are due to its labor intensity, in that the generation of new vaccine for each patient is time consuming and technically challenging. Furthermore, the yield from in vitro cell expansion is often insufficient. Each preparation of the vaccine requires the expansion of a tumor explant into a homogeneous culture, followed by GM-CSF gene transfer, cell selection, cell expansion, assays for GM-CSF secretion level, and irradiation before the vaccine can be used. There is also a critical relationship between the quantity of GM-CSF produced by the vaccinating cell population and the potency of the systemic antitumor immune response [75]. All of these limitations have prompted the generation of new vaccine strategies to avoid the technical difficulties encountered using this method.

\section{Allogeneic GM-CSF Transduced Cell-Based Vaccines}

The use of allogeneic vaccines can decrease the labor intensity and variability of vaccine production. With this strategy, a single standardized GM-CSF transduced cell line or a mixture of GM-CSF transduced cell lines is used to generate the vaccine. Critical to any chance of success with a transduced allogeneic tumor vaccine is that the allogeneic vaccines share antigens with the patient's tumor [75]. This is not a problem for most HPV-associated cervical cancers since they have shared common TSAs, E6 and E7. Recently, it has been shown that the professional APCs of the host rather than the vaccinating tumor cells themselves prime the $\mathrm{T}$ cell arm of the immune response [67]. This implies that the vaccinating cells used as the source of tumor antigens do not have to be MHC compatible with the host for successful priming of an antitumor immune response. Indeed, allogeneic tumor cells have been shown to generate protective antitumor immunity in immunized mice [164]. Currently, a phase I clinical trial evaluating an allogeneic, GM-CSF secreting tumor vaccine in patients with advanced pancreatic adenocarcinoma is in progress [Jaffee, pers. commun.].

\section{Bystander GM-CSF Releasing Microspheres or Cells}

Another possible solution to the difficulties surrounding in vitro cell culture and individualized cytokine gene 
transfer is to bypass the tumor cell itself. The appreciation of the paracrine physiology and potent antitumor effect of GM-CSF and the success that polymer-controlled drug delivery systems have had on improving certain drug therapies [82] has led to the design of cell-sized polymer microspheres containing GM-CSF [112]. The idea behind the design is that the microspheres would degrade over time, releasing a continued, controlled supply of GM-CSF in the vicinity of tumor cells. Pettit et al. [114] have described the preparation and characterization of a controlled release formulation of GM-CSF encapsulated in microspheres. They reported that steady release of GMCSF was achieved over a period of time without a significant 'burst' of protein from the microspheres and GMCSF released from the microspheres was found to be biologically active and physically intact by bioassay and chromatographic analysis [114].

Golumbek et al. [52] have used high doses of GM-CSF encapsulated in cell-sized gelatin-chondroitin sulfate microspheres to mix with irradiated tumor cells for vaccination. They found that GM-CSF initially released from the microspheres attracted and activated inflammatory cells, which in turn produced extracellular enzymes that degraded the collagen/chondroitin sulfate microsphere matrix. The rapid degradation resulted in increased GMCSF delivery, which amplified the process. When B16/ F10 melanoma cells were used in C57BL/6 mice, the microsphere containing GM-CSF admixed with irradiated tumor cells resulted in the same specific cytokine effect as that induced by GM-CSF transduced tumor cells [52].

Another approach is to use bystander GM-CSF releasing cells mixed with irradiated tumor cells. Several studies have used cytokine-secreting fibroblasts admixed with tumor cells in animal models $[137,157]$ and even in human cancer patients [86]. Fibroblasts are easily accessible via skin biopsies. In addition, the high GM-CSF secreting allogeneic/syngeneic fibroblasts can be selected before mixing with irradiated tumor cells in order to achieve a therapeutic level of GM-CSF. The relative efficacy of GM-CSF transduced allogeneic versus syngeneic fibroblasts admixed with tumor cells has been recently examined in mice by Aruga et al. [5]. They have shown that the syngeneic fibroblasts were superior to allogeneic fibroblasts as a vehicle to deliver GM-CSF in tumor vaccines. The use of allogeneic fibroblasts was associated with suppressed immune responses when used in high fibroblast:tumor cell ratios. Therefore, allogeneic GMCSF transduced fibroblasts may not be suitable in clinical settings [5].
The GM-CSF story provides a model for cytokinemodified tumor cell vaccines. Cytokines other than GMCSF have also been successfully applied in tumor-cellbased vaccine by using similar strategies as those used for GM-CSF [39, 77, 169, for review, see ref. 112].

\section{Vaccine Strategies Related to Flt 3 Ligand}

Flt3 Ligand and Development of Dendritic Cells in vivo

Flt3-L has emerged as an important molecule for the development of tumor vaccines that augments the function and quantity of DCs in vivo. Flt 3 (fms-like tyrosine kinase 3), a murine tyrosine kinase receptor, was first described in $1991[95,130]$ and found to be a member of the same family of receptors as c-kit and c-fms receptors the type III receptor kinase family [for review, see ref. 88]. Flt 3 is expressed in lymphohematopoietic tissues, placenta, brain, and a high proportion of leukemia and lymphoma cell lines [87]. In hematopoietic tissues, expression is restricted to the CD34-positive progenitors, including cells with the capacity for long-term reconstitution of irradiated hosts. Flt 3 has been used to identify and subsequently clone the corresponding ligand, Flt3-L [60, 90]. Flt3-L is a member of a small family of growth factors that stimulate the proliferation of hematopoietic cells. The predominant form of Flt3-L is synthesized as a transmembrane protein from which the soluble form is generated, presumably by proteolytic cleavage [89]. These proteins function by binding to and activating unique tyrosine kinase receptors. Expression of the Flt 3 receptor is primarily restricted, among hematopoietic cells, to the most primitive progenitor cells. Flt $3-\mathrm{L}$ alone has a weak stimulatory effect on in vitro progenitor cell colony growth but has additive or synergistic effects when combined with GM-CSF, granulocyte-CSF, IL-3, IL-11, IL12 , erythropoietin, stem cell factor, and other cytokines $[18,25,74]$. Recently, Flt3-L has been noted to possess a growth-stimulatory effect on DCs and to be capable of generating large numbers of DCs in vivo $[93,139]$. It has also been shown that Flt3-L, in cooperation with TGF- $\beta 1$, potentiates in vitro development of Langerhans-type DCs $[147,148]$. Because of the association of Flt $3-\mathrm{L}$ with the development of DCs, several studies have aimed at developing vaccines using Flt3-L or tumor cells expressing Flt3-L for antitumor immunity.

\section{Vaccine Strategies using the Flt3 Ligand}

There are several successful studies using Flt3-L and/ or tumor cells expressing Flt3-L for controlling murine tumors. For example, Lynch et al. [91] have reported an 
effective treatment of murine fibrosarcoma by Flt3-L therapy. They showed that Flt3-L treatment not only induced complete tumor regression in a significant proportion of mice, but also decreased tumor growth rate in the remaining mice [91]. Similarly, Chen et al. [25] used a murine breast cancer model and found that Flt3-L had antitumor properties. More recently, Esche et al. [48] have demonstrated that Flt3-L administration inhibits tumor growth in murine melanoma and lymphoma models. They observed an increase of DCs within these challenged tumor sites [48]. These data are consistent with the hypothesis that the generation of an effective immune response to the tumor may be related to the augmented generation of DCs in the vaccinated animal by Flt3-L treatment.

All of these exciting reports indicate that vaccine strategies that enhance the function and quantity of DCs in vivo may lead to effective control of tumor and can potentially be applied to human trials. It is conceivable that all of the vaccine strategies related to GM-CSF can be applied to the newly identified cytokine, Flt3-L. Furthermore, the combination of GM-CSF and Flt3-L in tumor vaccine design can potentially generate the greatest number of DCs and the most potent antitumor immunity.

\section{Tumor Cell Vaccines Enhancing T Cell Activation}

Tumor cells transduced with MHC molecules, costimulators or CD40L can enhance their immunogenicity and lead to $T$ cell activation. Tumor cells transduced with MHC molecules and costimulators may behave like APCs and are capable of presenting TSAs to the T cells. Tumor cells expressing MHC-II molecules are highly immunogenic [3]. The increased immunogenicity of MHC-II transfected tumor cells may be related to the induction of B7-1 and B7-2 costimulatory molecules expression by the MHC-II [107]. The expression of the costimulatory ligand B7-1 on murine melanoma cells $[26,167]$ or prostate cancer [81] was found to be capable of inducing CTL activities and controlling the murine melanoma or prostate cancer in vivo.

There is another cell-based vaccine capable of enhancing tumor-specific $T$ cells in vivo. Autologous tumor cells can be modified in vitro with cytokines and subsequently treated with bispecific monoclonal Abs to generate effective tumor-cell-based vaccines [59]. Culture of tumor cells with a combination of IFN- $\gamma$ and TNF- $\alpha$ significantly enhanced the expression of MHC-I and adhesion molecules on tumor surfaces. When these cytokine-treated tumor cells were subsequently incubated with a bispecific monoclonal $\mathrm{Ab}$ that binds antigen on tumor cells to $\mathrm{CD} 28$ on $T$ cells, the modified tumor cells become immunogenic and are able to stimulate naive $T$ cells, generating tumorspecific CTLs in vitro [59]. Immunization with the modified tumor cells is capable of protecting mice against a challenge with parental tumor cells and curing mice with established tumors. The approach was effective in both low immunogenic and nonimmunogenic tumor model systems [59].

Recently, CD40 ligand (CD40L) is found to play an important role in the cell-mediated immune response and T-cell-mediated effector functions [56]. CD40L is expressed by activated $\mathrm{CD} 4+\mathrm{T}$ cells while the CD40 (CD40L receptor) is expressed on APCs such as DCs, activated macrophage and $B$ cells. The interaction between the CD40L on the CD40L-transduced tumor cells and CD40 on the APC induces the expression of multiple costimulatory molecules on APCs and thus enhances the antigen presentation and provides the second signal for full $T$ cell activation. Grossmann et al. [57] showed that mice injected with CD40L-transduced tumor cells had resulted in a significant reduction in averaged tumor size and longer survival. Furthermore, vaccination with CD40L-transduced tumor cells protected mice from subsequent challenge with parental tumor cells $[44,57]$.

\section{Other Potential Cancer Vaccines}

Other potential cancer vaccines with significant promise are being actively explored. Abs have been used for the design of cancer vaccines. One approach is to use tumorspecific Abs coupled with isotopes, toxin or drugs for effective tumor killing [for review, see ref. 136]. Another approach is to use $\mathrm{Ab}$ against cytotoxic T-lymphocyteassociated molecule-4 (CTLA-4). CTLA-4, a second counterreceptor for the $\mathrm{B} 7$ family of costimulatory molecules, functions as a negative regulator of $\mathrm{T}$-cell activation [172]. Blocking the function of CTLA-4 may release the inhibition of ' $\mathrm{T}$ cell response and enhance the antitumor immunity. Administration of anti-CTLA-4 monoclonal $\mathrm{Ab}$ resulted in marked reduction in tumor growth or complete rejection of the tumor cells in murine prostate cancer cell [81], colorectal and fibrosarcoma models [83]. However, anti-CTLA-4 Ab was only effective in the early stage of tumor growth. It failed to enhance the in vivo and in vitro $T$ cell responses in late stage tumors [181]. Recently, T-cell-independent antitumor response has been described in mice reconstituted with bone marrow cells retrovirally transduced with an $\mathrm{Ab} / \mathrm{Fc}-\gamma$ chain chimeric receptor gene. The chimeric receptor gene is made by 
joining the heavy and light chain variable regions of a monoclonal $\mathrm{Ab}$ to a signal transducing domain which initiates cellular activation of $T$ cells. $T$ cells transduced with a chimeric receptor gene against human ovarian cancer were able to recognize ovarian cancer cells in vitro and in vivo [69]. More recently, Wang et al. [174] reported significant antitumor activity in mouse recipients of bone marrow cells transduced with this gene. Moreover, in vivo depletion of $T$ cells in reconstituted mice did not affect antitumor activity, suggesting that other immune cells expressing the chimeric receptor gene may play an important role in tumor rejection [174].

\section{Summary and Conclusions}

In the past decade, significant progress has been made in the field of cancer immunotherapy. Several experimental vaccines including vector-based vaccines, peptidebased vaccines, protein-based vaccines, DNA-based vaccines, and cell-based vaccines have been shown to generate impressive antitumor responses in murine tumor systems. In addition, it is now clear that DCs have become a central player for tumor vaccine development because of their ability to activate both CD8+ CTLs and CD4+ helper $T$ cells. The advances in DC biology have made it possible to generate large numbers of active DCs in vivo and ex vivo using key cytokines such as GM-CSF and Flt3-L. Impressive progress has been made in the development of vaccine strategies that employ DCs in vivo and ex vivo. Furthermore, some of these vaccine strategies have also been used for the phase I/II studies in cancer patients. The initial encouraging results for experimental vaccination systems emphasize the need to accelerate the pace of exploration in these systems. Although it is still difficult to generate a dramatic therapeutic response by tumor vaccines in patients with bulky tumor burdens, cancer vaccines are likely to be effective in patients with minimal residual tumor burdens. With the improved understanding of basic immunological mechanisms of tumor rejection, more potent tumor vaccine strategies may be developed in the future. It is fair to say some of these experimental vaccine strategies discussed in this review may prove to be useful for the prevention and treatment of cancers. Clinical usage of tumor vaccines employing strategies outlined in this review should be promising.

\section{Acknowledgments}

This review is not intended to be an encyclopedic one and we apologize to the authors not cited. We would like to thank Drs. DingShinn Chen, Jin-Chuan Sheu, Ken-Yu Lin, Matthew L. Kashima, Robert J. Kurman and Drew M. Pardoll for helpful discussions and critical review of the manuscript.

\section{References}

1 Aicher A, Westermann J, Cayeux S, Willimsky G, Daemen K, Blankenstein T, Uckert W, Dorken B, Pezzutto A. Successful retroviral mediated transduction of a reporter gene in human dendritic cells: Feasibility of therapy with gene-modified antigen presenting cells. Exp Hematol 25:39-44;1997.

2 Akagi J, Hodge JW, McLaughlin JP, Gritz L, Mazzara G, Kufe D, Schlom J, Kantor JA. Therapeutic antitumor response after immunization with an admixture of recombinant vaccinia viruses expressing a modified MUC1 gene and the murine T-cell costimulatory molecule B7. J Immunother 20:38-47;1997.

3 Armstrong TD, Clements VK, Martin BK, Ting JPY, Ostrand-Rosenberg S. Major histocompatibility complex class II-transfected tumor cells present endogenous antigen and are potent inducers of tumor-specific immunity. Proc Nat1 Acad Sci USA 94:6886-6891;1997.
4 Arthur JF, Butterfield LH, Roth MD, Bui LA, Kiertscher SM, Lau R, Dubinett S, Glaspy J, McBride WH, Economou JS. A comparison of gene transfer methods in human dendritic cells. Cancer Gene Ther 4:17-25;1997.

5 Aruga A, Aruga E, Chang AE: Reduced efficacy of allogeneic versus syngeneic fibroblasts modified to secrete cytokines as a tumor vaccine adjuvant. Cancer Res 57:3230-3237;1997.

6 Ashley DM, Faiola B, Nair S, Hale LP, Bigner DD, Gilboa E. Bone marrow-generated dendritic cells pulsed with tumor extracts or tumor RNA induce antitumor immunity against central nervous system tumors. J Exp Med 186: 1177-1182;1997.

7 Austyn JM. New insights into the mobilization and phagocytic activity of dendritic cells. J Exp Med 183:1287-1292;1996.
8 Bello-Fernandez C, Matyash M, Strobl H, Pickl WF, Majdic O, Lyman SD, Knapp W. Efficient retrovirus-mediated gene transfer of dendritic cells generated from $\mathrm{CD} 34+$ cord blood cells under serum-free conditions. Hum Gene Ther 8:1651-1658:1997.

9 Bender A, Sapp M, Schuler G, Steinman RM, Bhardwaj N. Improved methods for the generation of dendritic cells from nonproliferating progenitors in human blood. J Immunol Methods 196:121-135;1996.

10 Boczkowski D, Nair SK, Snyder D, Gilboa E. Dendritic cells pulsed with RNA are potent antigen-presenting cells in vitro and in vivo. $J$ Exp Med 184:465-472;1996

11 Borysiewicz LK, Fiander A, Nimako M, Man $S$, Wilkinson GW, Westmoreland D, Evans AS, Adams M, Stacey SN, Boursnell ME, Rutherford $\mathrm{E}$, Hickling JK, Inglis SC. A recombinant vaccinia virus encoding human papillomavirus types 16 and 18, E6 and E7 proteins as immunotherapy for cervical cancer. Lancet 347 : 1523-1527;1996. 
12 Bramson JL, Hitt M, Addison CL, Muller WJ, Bauldie J, Graham FL. Direct intratumoral injection of an adenovirus expressing interleur kin-12 induces regression and long-lasting immunity that is associated with highly localized expression of interleukin-12. Hum Gene Ther 7:1995-2002;1996.

13 Bramson JL, Hitt M, Gauldie J, Graham FL Pre-existing immunity to adenovirus does not prevent tumor regression following intratumoral administration of a vector expressing $I L-12$ but inhibits virus dissemination. Gene Ther 4 : 1069-1076;1997.

14 Breel M, Laman J, Kraal G. Murine hybrid cell lines expressing the NLDC-145 dendritic cell determinant. Immunobiology 178:167--176; 1988.

15 Bright RK, Beames B, Shearer MH, Kennedy RC. Protection against a lethal challenge with SV 40-transformed cells by the direct injection of DNA encoding SV40 large tumor antigen. Cancer Res 56:1126-1130;1996.

16 Bronte V, Carroll MW, Goletz TJ, Wang M, Overwijk WW, Marincola F, Rosenberg SA, Moss B, Restifo NP. Antigen expression by dendritic cells correlates with the therapeutic effectiveness of a model recombinant poxvirus tumor vaccine. Proc Natl Acad Sci USA 94: 3183-3188;1997.

17 Brossart P, Goldrath AW, Butz EA, Martin S, Bevan MJ. Vinus-mediated delivery of antigenic epitopes into dendritic cells as a means to induce CTL. $J$ Immunol 158:3270-3276;1997.

18 Broxmeyer HE, Lu L, Cooper S, Ruggieri L, Li $\mathrm{ZH}$, Lyman SD. Flt3 ligand stimulates/costimulates the growth of myeloid stem/progenitor cells. Exp Hematol 23:1121-1129:1995.

19 Caruso M, Pham-Nguyen K, Kwong YL, Xu B, Kosai KI, Finegold M, Woo SL, Chen SH. Adenovirus-mediated interleukin-12 gene therapy for metastatic colon carcinoma. Proc Nat1 Acad Sci USA 93:1 1302-11306;1996.

20 Caux C, Dezutter-Dambuyant C, Schmitt D, Banchereau J. GM-CSF and TNF-alpha cooperate in the generation of dendritic Langerhans cells. Nature 360:258-261:1992.

21 Caux C, Vanbervliet B, Massacrier C, Dezutter-Dambuyant C, de Saint-Vis B, Jacquet C, Yoneda $K$, Imamaura S, Schmitt D, Banchereau J. CD 34 + hematopoietic progenitors from human cord blood differentiate along two independent dendritic cell pathways in response to GM-CSF+TNF alpha. I Exp Med 184:695706:1996.

22 Cella M, Engering A, Pinet V, Pieters J, Lanzavechia A. Inflammatory stimuli induce accumulation of MHC class II complexes on dendritic cells. Nature 388:782-787;1997.

23 Cella M, Sallusto F, Lanzavecchia A. Origin, maturation and antigen presenting function of dendritic cells. Curr Opin Immunol 9:10-16; 1997.

24 Chamberlain RS, Carroll MW, Bronte V, Hwu P, Warren S, Yang JC, Nishimura M, Moss B, Rosenberg SA, Restifo NP. Costimulation enhances the active immunotherapy effect of recombinant anticancer vaccines. Cancer Res 56 : 2832-2836:1996.
25 Chen $K$, Braun S, Lyman S, Fan Y, Traycoff CM, Wiebke EA, Gaddy J, Sledge G, Broxmeyer HE, Cornetta $\mathrm{K}$. Antitumor activity and immunotherapeutic properties of Flt3-ligand in a murine breast cancer model. Cancer Res 57:3511-3516;1997.

26 Chen L, Ashe S, Brady WA, Hellstrom I, Hellstrom KE, Ledbetter JA, McGowan P, Linsley PS. Costimulation of antitumor immunity by the $B 7$ counterreceptor for the $T$ lymphocyte molecules CD28 and CTLA-4. Cell 71:1093$1102 ; 1992$.

27 Chen L, Chen D, Block E, O'Donnell M, Kufe DW, Clinton SK. Eradication of murine bladder carcinoma by intratumor injection of a bicistronic adenoviral vector carrying cDNAs for the IL- 12 heterodimer and its inhibition by the IL-12 p40 subunit homodimer. J Immunol 159:351-359:1997.

28 Chen PW, Wang M, Bronte V, Zhai Y, Rosenberg SA, Restifo NP. Therapeutic antitumor response after immunization with a recombinant adenovirus encoding a model tumor-associated antigen. $J$ Immunol 156:224-231;1996.

29 Chen TT, Tao MH, Levy R. Idiotype-cytokine fusion proteins as cancer vaccines. Relative efficacy of IL-2, IL-4, and granulocyte-macrophage colony-stimulating factor. J Immunol 153:4775-4787;1994.

30 Chow YH, Chiang BL, Lee YL, Chi WK, Lin WC, Chen YT, Tao MH. Development of Th1 and $T h 2$ populations and the nature of immune responses to hepatitis $B$ virus DNA vaccines can be modulated by codelivery of various cytokine genes. J Immunol 160:1320-1329; 1998.

31 Chu RS, Targoni OS, Krieg AM, Lehmann PV, Harding CV. CpG oligodeoxynucleotides act as adjuvants that switch on $\mathrm{T}$ helper 1 (Th1) immunity. J Exp Med 186:1623-1631;1997.

32 Ciernik IF, Berzofsky JA, Carbone DP. Induction of cytotoxic T lymphocytes and antitumor immunity with DNA vaccines expressing single T cell epitopes. J Immunol 156:2369-2375; 1996.

33 Collins DS, Findlay K, Harding CV. Processing of exogenous liposome-encapsulated antigens in vivo generates class I MHC-restricted T cell responses. J Immunol 148:3336-3341; 1992.

34 Condon C, Watkins SC, Celluzzi CM, Thompson K. Falo LD Jr. DNA-based immunization by in vivo transfection of dendritic cells. Nat Med 2:1122-1128;1996.

35 Conry RM, LoBuglio AF, Loechel F, Moore SE, Sumerel LA, Barlow DL, Curiel DT. A carcinoembryonic antigen polynucleotide vaccine has in vivo antitumor activity. Gene Ther 2: $59-65 ; 1995$

36 Corr M, Tighe H, Lee D, Dudler J, Trieu M, Brinson DC, Carson DA. Costimulation provided by DNA immunization enhances antitumor immunity. J Immunol 159:4999-5004; 1997.

37 Coveney E, Wheatley GH 3rd, Lyerliy HK. Active immunization using dendritic cells mixed with tumor cells inhibits the growth of primary breast cancer. Surgery 122:228- 234; 1997.
38 Darji A, Guzman CA, Gerstel B, Wachholz P, Timmis KN, Wehland J, Chakraborty T, Weiss S. Oral somatic transgene vaccination using attenuated S. typhimurium. Cell 91:765-775; 1997.

39 Das Gupta TK, Cohen EP, Richards JM. Phase I evaluation of interleukin-2-transfected irradiated allogeneic melanoma for the treatment of metastatic melanoma: Appendix 1: Protocol. Hum Gene Ther 8:1701-1714;1997.

40 De Bruijn MLH, Schuurhuis DH, Vierboom MPM, Vermeulen H, de Cock KAJ, Ooms ME, Ressing ME, Toebes M, Franken KL, Drijfhout $J W$, Ottenhoff THM, Offringa R, Melief CJM. Immunization with human papillomavirus type 16 (HPV 16) oncoprotein-loaded dendritic cells as well as protein in adjuvant induces MHC class I-restricted protection to HPV16induced tumor cells. Cancer Res 58:724-731; 1998.

41 Deres $\mathrm{K}$, Schild $\mathrm{H}$, Wiesmuller $\mathrm{KH}$, Jung $\mathrm{G}$ Rammensee HG. In vivo priming of virus-specific cytotoxic $T$ lymphocytes with synthetic lipopeptide vaccine. Nature 342:561-564; 1989.

42 Descamps V, Duffour MT, Mathieu MC, Fernandez N, Cordier L, Abina MA, Kremer E, Perricaudet M, Haddada H. Strategies for cancer gene therapy using adenoviral vectors. $\mathrm{J}$ Mol Med 74:183-189;1996.

43 Dietz AB, Vuk-Pavlovic S. High efficiency adenovirus-mediated gene transfer to human dendritic cells. Blood 91:392-398;1998.

44 Dilloo D, Brown M, Roskrow M, Zhong W, Holladay M, Holden W, Brenner M. CD40 ligand induces an antileukemia immune response in vivo. Blood 90:1927-1933;1997.

45 Donnelly JJ, Ulmer JB, Shiver JW, Liu MA. DNA vaccines. Annu Rev Immunol 15:617$648 ; 1997$.

46 Dranoff G, Jaffee E, Lazenby A, Golumbek P, Levitsky $H$, Brose $K$, Jackson V, Hamada $H$ Pardoll D, Mulligan RC. Vaccination with irradiated tumor cells engineered to secrete murine granulocyte-macrophage colony-stimulating factor stimulates potent, specific, and long-lasting anti-tumor immunity. Proc Natl Acad Sci USA 90:3539-3543;1993.

47 Dranoff G, Soiffer R, Lynch T, Mihm M, Jung $\mathrm{K}$, Kolesar K, Liebster L, Lam P, Duda R, Mentzer S, Singer $S$, Tanabe $K$, Johnson $R$, Sober A, Bhan A, Clift S, Cohen L, Parry G, Rokovich J, Richards L, Drayer J, Berns A, Mulligan RC. A phase I study of vaccination with autologous, irradiated melanoma cells engineered to secrete human granulocyte-macrophage colony stimulating factor. Hum Gene Ther 8:111-123;1997.

48 Esche C, Subbotin V, Maliszewski C, Lotze M, Shurin M. Flt3 ligand administration inhibits tumor growth in murine melanoma and lymphoma. Cancer Res 58:380-383;1998.

49 Feltkamp MC, Smits HL, Vierboom MP, Minnaar RP, de Jongh BM, Drijfhout JW, ter Schegget J, Melief CJ, Kast WM. Vaccination with cytotoxic $\mathrm{T}$ lymphocyte epitopecontaining peptide protects against a tumor induced by human papillomavirus type 16-transformed cells. Eur J Immunol 23:2242-2249; 1993. 
50 Geissler M, Wands G, Gesien A, de la Monte S, Bellet D, Wands JR. Genetic immunization with the free human chorionic gonadotropin beta subunit elicits cytotoxic T lymphocyte responses and protects against tumor formation. in mice. Lab Invest 76:859-871;1997.

51 Germain RN. MHC-dependent antigen processing and peptide presentation: Providing ligands for $T$ lymphocyte activation (review). Cell 76:287-299;1994.

52 Golumbek PT, Azhari R, Jaffee EM, Levitsky HI, Lazenby A, Leong K, Pardoll DM. Controlled release, biodegradable cytokine depots: A new approach in cancer vaccine design. Cancer Res 53:5841-5844;1993.

53 Gonczol E, Berensci K, Pincus S, Endresz V, Meric C, Paoletti E, Plotkin SA. Preclinical evaluation of an ALVAC (canarypox)-human cytomegalovirus glycoprotein $B$ vaccine candidate. Vaccine 13:1080-1085;1995.

54 Gong J, Chen D, Kashiwaba M, Kufe D. Induction of antitumor activity by immunization with fusions of dendritic and carcinoma cells. Nat Med 3:558-561;1997.

55 Greenstone HL, Nieland JD, de Visser KE, De Bruijn MLH, Kirnbauer R, Roden RBS, Lowy DR, Kast WM, Schiller JT. Chimeric papillomavirus virus-like particles elicit antitumor immunity against the E7 oncoprotien in an HPV16 tumor model. Proc Natl Acad Sci USA 95:1800-1805;1998.

56 Grewal IS, Borrow P, Pamer EG, Oldstone MB, Flavell RA. The CD40-CD154 system in anti-infective host defense. Curr Opin Immunol 9:491-497;1997.

57 Grossmann ME, Brown MP, Brenner MK. Antitumor responses induced by transgenic expression of CD40 ligand. Hum Gene Ther 8: 1935-1943;1997.

58 Guo $\mathrm{Y}, \mathrm{Wu} \mathrm{M}$, Chen $\mathrm{H}$, Wang $\mathrm{X}, \mathrm{Liu} \mathrm{G}, \mathrm{Li} \mathrm{G}$, Ma $J$, Sy MS. Effective tumor vaccine generated by fusion of hepatoma cells with activated B cells. Science 263:518-520;1994.

59 Guo YJ, Che XY, Shen F, Xie TP, Ma J, Wang $\mathrm{XN}, \mathrm{Wu} \mathrm{SG}$, Anthony DD, Wu MC. Effective tumor vaccines generated by in vitro modification of tumor cells with cytokines and bispecific monoclonal antibodies. Nat Med 3:451455;1997.

60 Hannum C, Culpepper J, Campbell D, McClanahan T, Zurawski S, Bazan JF, Kastelein R, Hudak S, Wagner J, Mattson J, et al, Ligand for FLT3/FLK2 receptor tyrosine kinase regulates growth of haematopoietic stem cells and is encoded by variant RNAs. Nature 368:643$648 ; 1994$.

61 Harding CV, Song R. Phagocytic processing of exogenous particulate antigens by macrophages for presentation by class I MHC molecules. $J$ Immunol 153:4925-4933;1994.

62 Hariharan K, Braslawsky G, Black A, Raychaudhuri S, Hanna $N$. The induction of cytotoxic $\mathrm{T}$ cells and tumor regression by soluble antigen formulation. Cancer Res 55:34863489;1995.

63 Hart DN. Dendritic cells: Unique leukocyte populations which control the primary immune response (review). Blood 90:3245-3487; 1997.
64 Herbst B, Kohler G, Mackensen A, Veelken H, Kulmburg P, Rosenthal FM, Schaefer HE, Mertelsmann R, Fisch P, Lindenmann A. In vitro differentiation of $\mathrm{CD} 34+$ hematopoietic progenitor cells toward distinct dendritic cell subsets of the Birbeck granule and MIIC-positive Langerhans cell and the interdigitating dendritic cell type. Blood 88:2541-2548;1996.

65 Heufler C, Koch F, Schuler G. Granulocyte/ macrophage colony-stimulating factor and interleukin 1 mediate the maturation of murine epidermal Langerhans cells into potent immunostimulatory dendritic cells. J Exp Med 167: 700-705;1988.

66 Hsu FJ, Benike C, Fagnoni F, Liles TM, Czerwinski D, Taidi B, Engleman EG, Levy R. Vaccination of patients with B-cell lymphoma using autologous antigen-pulsed dendritic cells. Nat Med 2:52-58;1996.

67 Huang AY, Golumbek P, Ahmadzadeh M, Jaffee E, Pardoll D, Levitsky H. Role of bone marrow-derived cells in presenting MHC class Irestricted tumor antigens. Science 264:961$965 ; 1994$.

68 Huang H, Chen SH, Kosai K, Finegold MJ, Woo SL. Gene therapy for hepatocellular carcinoma: Long-term remission of primary and metastatic tumors in mice by interleukin-2 gene therapy in vivo. Gene Ther 3:980-987; 1996.

69 Hwu P, Yang JC, Cowherd R, Reisman J, Shafer GE, Eshhar Z, Rosenberg SA. In vivo antitumor activity of $T$ cells redirected with chimeric antibody/T-cell receptor genes. Cancer Res 55: 3369-3373;1995.

70 Inaba K, Inaba M, Romani N, Aya H, Deguchi M, Ikehara S, Muramatsu S, Steinman RM. Generation of large numbers of dendritic cells from mouse bone marrow cultures supplemented with granulocyte/macrophage colonystimulating factor. J Exp Med 176:1693-1702; 1992.

71 Inaba K, Steinman RM, Pack MW, Aya H, Inaba M, Sudo T, Wolpe S, Schuler G. Identification of proliferating dendritic cell precursors in mouse blood. J Exp Med 175:1157-1167; 1992.

72 Irvine KR, Chamberian RS, Shulman EP, Surman DR, Rosenberg SA, Restifo NP. Enhancing efficacy of recombinant anticancer vaccines with prime/boost regimens that use two different vectors. J Natl Cancer Inst 89:1595-1601; 1997.

73 Irvine KR, Rao JB, Rosenberg SA, Restifo NP. Cytokine enhancement of DNA immunization leads to effective treatment of established pulmonary metastases. J Immunol 156:238-245; 1996.

74 Jacobsen SE, Veiby OP, Myklebust J, Okkenhaug C, Lyman SD. Ability of flt 3 ligand to stimulate the in vitro growth of primitive murine hematopoietic progenitors is potently and directly inhibited by transforming growth factor-beta and tumor necrosis factor-alpha. Blood 87:5016-5026;1996.
75 Jaffee EM, Pardoll DM. Considerations for the clinical development of cytokine gene-transduced tumor cell vaccines. Methods 12:143153;1997.

76 Jondal M, Schirmbeck R, Reimann J. MHC class I-restricted CTL responses to exogenous antigens (review). Immunity 5:295-302;1996.

77 Karpoff HM, D'Angelica M, Blair S, Brownlee MD, Federoff H, Fong Y. Prevention of hepatic tumor metastases in rats with herpes viral vaccines and gamma-interferon. J Clin Invest 99:799-804;1997.

78 Kay MA, Liu D, Hoogerbrugge PM. Gene therapy. Proc Natl Acad Sci USA 94:12744-12746; 1997.

79 Kim CJ, Prevette T, Cormier J, Overwijk W, Roden M, Restifo NP, Rosenberg SA, Marincola FM. Dendritic cells infected with poxviruses encoding MART-1/Melan A sensitize T lymphocytes in vitro. J Immunother $20: 276-$ $286 ; 1997$.

80 Kovacsovics-Bankowski M, Clark K, Benacerraf B, Rock KL. Efficient major histocompatibility complex class I presentation of exogenous antigen upon phagocytosis by macrophages. Proc Natl Acad Sci USA 90:49424946;1993.

81 Kwon ED, Hurwitz AA, Foster BA, Madias C, Feldhaus AL, Greenberg NM, Burg MB, Allison JP. Manipulation of $\mathrm{T}$ cell costimulatory and inhibitory signals for inmunotherapy of prostate cancer. Proc Natl Acad Sci USA 94: 8099-8103;1997.

82 Langer R, Cima LG, Tamada JA, Wintermantel E. Future directions in biomaterials. Biomaterials $11: 738-745 ; 1990$.

83 Leach DR, Krummel MF, Allison JP. Enhancement of antitumor immunity by CTLA-4 blockade. Science 271:1734-1736;1996.

$84 \mathrm{Li} \mathrm{Z}$. Priming of $\mathrm{T}$ cells by heat shock proteinpeptide complexes as the basis of tumor vaccines. Semin Immunol 9:315-322;1997.

85 Lin KY, Guarnieri FG, Staveley-O'Carroll KF, Levitsky HI, August JT, Pardoll DM, Wu TC. Treatment of established tumors with a novel vaccine that enhances major histocompatibili. ty class II presentation of tumor antigen. Cancer Res 56:21-26;1996.

86 Lotze MT, Rubin JT, Carty S, Edington H, Ferson P, Landreneau R, Pippin B, Posner M, Rosenfelder D, Watson C, et al. Gene therapy of cancer: A pilot study of IL-4-gene-modified fibroblasts admixed with autologous tumor to elicit an immune response. Hum Gene Ther 5 : 41-55;1994.

87 Lyman SD. Biology of flt 3 ligand and receptor (review). Int J Hematol 62:63-73;1995.

88 Lyman SD, Jacobsen SEW. c-kit ligand and Fit3 ligand: Stem/progenitor cell factors with overlapping yet distinct activities. Blood 91 : 1101-1134;1998.

89 Lyman SD, James L, Escobar S, Downey H, de Vries $\mathrm{P}$, Brasel K, Stocking K, Beckmann MP, Copeland NG, Cleveland LS, et al. Identification of soluble and membrane-bound isoforms of the murine fit 3 ligand generated by alternative splicing of mRNAs. Oncogene 10:149$157 ; 1995$. 
90 Lyman SD, James L, Vanden Bos T, de Vries P, Brasel K, Gliniak B, Hollingsworth LT, Picha KS, McKenna HJ, Splett RR, et al. Molecular cloning of a ligand for the ftt $3 / \mathrm{flk}-2$ tyrosine kinase receptor: A proliferative factor for primitive hematopoietic cells. Cell 75: 1157-1167;1993.

91 Lynch DH, Andreasen A, Maraskovsky E, Whitmore J, Miller RE, Schuh JC. Flt3 ligand induces tumor regression and antitumor immune responses in vivo. Nat Med 3:625-631; 1997.

92 Mahvi DM, Sondel PM, Yang NS, Albertini MR, Schiller JH, Hank J, Heiner J, Gan J, Swain W, Logrono R. Phase I/IB study of immunization with autologous tumor cells transfected with the GM-CSF gene by particle-mediated transfer in patients with melanoma or sarcoma. Hum Gene Ther 8:875 891;1997.

93 Maraskovsky E, Brasel K, Teepe M, Roux ER, Lyman SD, Shortman K, McKenna HJ. Dramatic increase in the numbers of functionally mature dendritic cells in Flt3 ligandtreated mice: Multiple dendritic cell subpopulations identified. J Exp Med 184:1953-1962; 1996.

94 Marchand M, Weynants $P$, Rankin E, Arienti F, Belli F, Parmiani G, Cascinelli N, Bourlond A, Vanwijck R, Humblet $Y$, et al. Tumor regression responses in melanoma patients treated with a peptide encoded by gene MAGE-3 (letter). Int J Cancer 63:883-885; 1995.

95 Matthews W, Jordan CT, Wiegand GW, Pardoll $D$, Lemischka IR. A receptor tyrosine kinase specific to hematopoietic stem and progenitor cell-enriched populations. Cell 65: 1143-1152;1991.

96 Mayordomo II, Zorina T, Storkus WJ, Zitvogel L, Celluzzi C, Falo LD, Melief CJ, Ildstad ST, Kast WM, Deleo AB, et al. Bone marrowderived dendritic cells pulsed with synthetic tumour peptides elicit protective and therapeutic antitumour immunity. Nat Med 1: 1297-1302;1995.

97 Mayordomo JI, Zorina T, Storkus WJ, Zitvogel L, Garcia-Prats MD, DeLeo AB, Lotze MT. Bone marrow-derived dendritic cells serve as potent adjuvants for peptide-based antitumor vaccines (review). Stem Cells 15 : 94-103;1997.

98 McAneny D, Ryan CA, Beazley RM, Kaufman HL. Results of a phase I trial of a recombinant vaccinia virus that expresses carcinoembryonic antigen in patients with advanced colorectal cancer. Ann Surg Oncol 3: 495-500;1996.

99 Melief CJ, Offringa R, Toes RE, Kast WM. Peptidembased cancer vaccines (review). Curr Opin Immunol 8:651-657;1996.

100 Minev BR, McFarland BJ, Spiess PJ, Rosenberg SA, Restifo NP. Insertion signal sequence fused to minimal peptides elicits specific $\mathrm{CD} 8+\mathrm{T}$-cell responses and prolongs survival of thymoma-bearing mice. Cancer Res $54: 4155-4161 ; 1994$
101 Morse MA, Zhou LJ, Tedder TF, Lyerly HK, Smith C. Generation of dendritic cells in vitro from peripheral blood mononuclear cells with granulocyte-macrophage-colony-stimulating factor, interleukin-4, and tumor necrosis factor-alpha for use in cancer immunotherapy. Ann Surg 226:6-16;1997.

102 Moss B. Genetically engineered poxviruses for recombinant gene expression, vaccination, and safety. Proc Natl Acad Sci USA 93: 11341-11348;1996.

103 Murphy G, Tjoa B, Ragde H, Kenny G, Boynton A. Phase I clinical trial: T-cell therapy for prostate cancer using autologous dendritic cells pulsed with HLA-A0201-specific peptides from prostate-specific membrane antigen. Prostate 29:371-380;1996.

104 Nair SK, Boczkowski D, Snyder D, Gilboa E. Antigen-presenting cells pulsed with unfractionated tumor-derived peptides are potent tumor vaccines. Eur I Immunol 27:589-597; 1997.

105 Nair SK, Snyder D, Rouse BT, Gilboa E. Regression of tumors in mice vaccinated with professional antigen-presenting cells pulsed with tumor extracts. Int $\mathrm{J}$ Cancer 70:706715;1997.

106 Nestle FO, Alijagic S, Gilliet M, Sun Y, Grabbe S, Dummer R, Burg G, Schadendorf $D$. Vaccination of melanoma patients with peptide- or tumor lysate-pulsed dendritic cells. Nat Med 4:328-332;1998

107 Ostrand-Rosenberg S, Baskar S, Patterson N, Clements VK. Expression of MHC class II and $B 7-1$ and B7-2 costimulatory molecules accompanies tumor rejection and reduces the metastatic potential of tumor cells. Tissue Antigens 47:414-421;1996.

108 Paglia P, Chiodoni C, Rodolfo M, Colombo MP. Murine dendritic cells loaded in vitro with soluble protein prime cytotoxic T lymphocytes against tumor antigen in vivo. J Exp Med 183:317-322;1996.

109 Paglia P, Girolomoni G, Robbiati F, Granucci F, Ricciardi-Castagnoli P. Inmortalized dendritic cell line fully competent in antigen presentation initiates primary $\mathrm{T}$ cell responses in vivo. J Exp Med 178:1893-1901; 1993.

110 Pan ZK, Ikonomidis G, Lazenby A, Pardol $\mathrm{D}$, Paterson Y.A recombinant Listeria monocytogenes vaccine expressing a model tumour antigen protects mice against lethal tumour cell challenge and causes regression of established tumours. Nat Med 1:471-477;1995.

111 Pan ZK, Ikonomidis G, Pardoll D, Paterson $Y$. Regression of established tumors in mice mediated by the oral administration of a recombinant $L$ isteria monocytogenes vaccine. Cancer Res 55:5776-4779:1995.

112 Pardoll DM. Paracrine cytokine adjuvants in cancer immunotherapy. Annu Rev Immunol 13:399-415;1995

113 Peng S, Frazer IH, Fernando GJ, Zhou J. Papillomavirus virus-like particles can deliver defined CTL epitopes to the MHC class I pathway. Virology 240:147-157;1998.
114 Pettit DK, Lawter JR, Huang WJ, Pankey SC, Nightlinger NS, Lynch DH, Schuh JA, Morrissey PJ, Gombotz WR. Characterization of poly(glycolide-co-D,L-lactide)/poly(D,L-lactide) microspheres for controlled release of GM-CSF. Pharm Res 14:1422-1430;1997.

115 Pierre P, Turley SJ, Gatti E, Hull M, Meltzer J, Mirza A, Inaba K. Steinman RM, Mellman I. Developmental regulation of MHC class II transport in mouse dendritic cells. Nature 388:787-792;1997.

116 Plotkin SA, Cadoz M, Meignier B, Meric C, Leroy O, Excler IL, Tartaglia J, Paoletti E, Gonczol E, Chappuis G. The safety and use of canarypox vectored vaccines. Dev Biol Stand 84:165-170;1995.

117 Putzer BM. Hitt M, Muller WJ, Emtage P, Gauldie J, Graham FL. Interleukin 12 and B 7-1 costimulatory molecule expressed by an adenovirus vector act synergistically to facilitate tumor regression. Proc Natl Acad Sci USA 94:10889-10894;1997.

118 Rakhmilevich AL, Janssen K. Turner J, Culp J, Yang NS. Cytokine gene therapy of cancer using gene gun technology: Superior antitumor activity of interleukin-12. Hum Gene Ther 8:1303-1311;1997.

119 Rao JB, Chamberlain RS, Bronte V, Carroll MW, Irvine KR, Moss B, Rosenberg SA, Restifo NP. IL-12 is an effective adjuvant to recombinant vaccinia virus-based tumor vaccines: Enhancement by simuitaneous B T-1 expression. J Immunol 156:3357-3365;1996.

120 Raychaudhuri S, Tonks M, Carbone F, Ryskamp T, Morrow WJ, Hanna N. Induction of antigen-specific class I-restricted cytotoxic $\mathrm{T}$ cells by soluble proteins in vivo. Proc Natl Acad Sci USA 89:8308-8312;1992.

121 Reeves ME, Royal RE, Lam IS, Rosenberg SA, Hwu P. Retroviral transduction of human dendritic cells with a tumor-associated antigen gene. Cancer Res 56:5672-5677; 1996.

122 Restifo NP. The new vaccines: Building viruses that elicit antitumor immunity. Curr Opin Immunol 8:658-663;1996.

123 Ribas A, Butterfield LH, McBride WH, Jilani SM, Bui LA, Vollmer CM, Lau R, Dissette VB, Hu B, Chen AY, Glaspy JA, Economou JS. Genetic immunization for the melanoma antigen MART-1/Melan-A using recombinant adenvirus-transduced murine dendritic cells. Cancer Res 57:2865-2869;1997.

124 Robinson HL, Torres CA. DNA vaccines. Semin Immunol 9:271-283;1997.

125 Roman M, Martin-Orozco E, Goodman JS, Nguyen MD, Sato Y, Ronaghy A, Kornbluth RS, Richman DD, Carson DA, Raz E Immunostimulatory DNA sequences function as $T$ helper-1-promoting adjuvants. Nat Med 3: 849-854;1997.

126 Romani N, Gruner S, Brang D, Kampgen E, Lenz A, Trockenbacher B, Konwalinka G, Fritsch PO, Steinman RM, Schuler G. Prolifcrating dendritic cell progenitors in human blood. J Exp Med 180:83-93;1994. 
127 Rosato A, Zambon A, Milan G, Ciminale V, D'Agostino DM, Macino B, Zanovello P, Collavo $\mathrm{D}, \mathrm{CTL}$ response and protection against P815 tumor challenge in mice immunized with DNA expressing the tumor-specific antigen P815A. Hum Gene Ther 8:1451-1458; 1997.

128 Rosenberg SA, Lotze MT, Yang JC, Aebersold PM, Linehan WM, Seipp CA, White DE. Experience with the use of high-dose interleukin-2 in the treatment of 652 cancer patients. Ann Surg 210:474-484; discussion 484-485; 1989.

129 Rosenberg SA, Yang JC, Schwartzentruber DJ, Hwu P, Marincola FM, Topalian SL, Restifo NP, Dudley ME, Schwarz SL, Spiess PJ, Wunderiich JR, Parkhurst MR, Kawakami Y, Seipp CA, Einhorn JH, White DE. Immunologic and therapeutic evaluation of a synthetic peptide vaccine for the treatment of patients with metastatic melanoma. Nat Med 4:321-327;1998.

130 Rosnet O, Marchetto S, deLapeyriere $\mathrm{O}$, Birnbaum D. Murine Flt3, a gene encoding a novel tyrosine kinase receptor of the PDGFR/CSF1R family. Oncogene 6:1641$1650 ; 1991$.

131 Rouse RJ, Nair SK, Lydy SL, Bowen JC, Rouse BT. Induction in vitro of primary cytotoxic T-lymphocyte responses with DNA encoding herpes simplex virus proteins. J Virol 68:5685-5689;1994.

132 Sallusto F, Lanzavecchia A. Efficient presentation of soluble antigen by cultured human dendritic cells is maintained by granulocyte/ macrophage colony-stimulating factor plus interleukin 4 and downregulated by tumor necrosis factor alpha. J Exp Med 179:1109$1118 ; 1994$.

133 Schirmbeck R, Bohm W, Melber K, Reimann J. Processing of exogenous heat-aggregated (denatured) and particulate (native) hepatitis $B$ surface antigen for class I-restricted epitope presentation. J Immunol 155:4676-4684; 1995.

134 Schirmbeck R, Bohm W, Reimann J. DNA vaccination primes $\mathrm{MHC}$ class I-restricted, simian virus 40 large tumor antigen-specific CTL in $\mathrm{H}-2 \mathrm{~d}$ mice that rejects syngeneic tumors. J Immunol 157:3550-3558;1996.

135 Schmidt W, Buschle M, Zauner W, Kirlappos H, Mechtier K, Trska B, Birnstiel ML. Cellfree tumor antigen peptide-based cancer vaccines. Proc Natl Acad Sci USA 94:3262$3267 ; 1997$.

136 Scott AM, Welt S. Antibody-based immunological therapies. Curr Opin Immunol 9:717$722 ; 1997$.

137 Shawler DL, Dorigo O, Gjerset RA, Royston I, Sobol RE, Fakhrai H. Comparison of gene therapy with interleukin- 2 gene modified fibroblasts and tumor cells in the murine CT26 model of colorectal carcinoma. J Immu nother Emphasis Tumor Immunol 17:201208;1995.

138 Shen Z, Reznikoff G, Dranoff G, Rock KL. Cloned dendritic cells can present exogenous antigens on both $\mathrm{MHC}$ class I and class II molecules. J Immunol 158:2723-2730;1997.
139 Shurin MR, Pandharipande PP, Zorina TD, Haluszczak C, Subbotin VM, Hunter O, Brumfield A, Storkus WJ, Maraskovsky E, Lotze MT. FLT3 ligand induces the generation of functionally active dendritic cells in mice. Cell Immunol 179:174-184;1997.

140 Siena S, Di Nicola M, Bregni M, Mortarini R, Anichini A, Lombardi L, Ravagnani F, Parmiani G, Gianni AM. Massive ex vivo generation of functional dendritic cells from mobilized $C D 34+$ blood progenitors for anticancer therapy. Exp Hematol 23:1463-1471:1995.

141 Simons JW, Jaffe EM, Weber CE, Levitsky HI, Nelson WG, Carducei MA, Lazenby AJ, Cohen LK, Finn CC, Clift SM, Hauda KM, Beck LA, Leiferman KM, Owens AH Jr, Piantadosi S, Dranoff G, Mulligan RC, Pardoll DM, Marshall FF. Bioactivity of autologous irradiated renal cell carcinoma vaccines generated by ex vivo granulocyte-macrophage colony-stimulating factor gene transfer. Cancer Res 57:1537-1546;1997.

142 Song W, Kong HL, Carpenter H, Torii H, Granstein R, Rafii S, Moore MA, Crystal RG. Dendritic cells genetically modified with an adenovirus vector encoding the CDNA for a model antigen induce protective and therapeutic antitumor immunity. J Exp Med 186: 1247-1256:1997.

143 Specht JM, Wang G, Do MT, Lam JS, Royal RE, Reeves ME, Rosenberg SA, Hwu P. Dendritic cells retrovirally transduced with a model antigen gene are therapeutically effective against established pulmonary metastases. J Exp Med 186:1213-1221;1997.

144 Srivastava PK. Purification of heat shock protein-peptide complexes for use in vaccination against cancers and intracellular pathogens (review). Methods 12:165-171;1997.

145 Steinman RM. The dendritic cell system and its role in immunogenicity (review). Annu Rev Immunol 9:271-296;1991.

146 Storkus WJ, Zeh HJd, Salter RD, Lotze MT. Identification of T-cell epitopes: Rapid isolation of class I-presented peptides from viable cells by mild acid elution. $J$ Immunother 14 : 94-103;1993.

147 Strobl H, Bello-Fernandez C, Riedl E, Pickl WF, Majdic O, Lyman SD, Knapp W. flt 3 ligand in cooperation with transforming growth factor-beta 1 potentiates in vitro development of Langerhans-type dendritic cells and allows single-cell dendritic cell cluster formation under serum-free conditions. Blood 90:1425-1434;1997.

148 Strobl H, Riedl E, Scheinecker C, Bello-Fernandez C, Pick1 WF, Rappersberger K, Majdic $\mathrm{O}$, Knapp W. TGF-beta 1 promotes in vitro development of dendritic cells from CD34+ hemopoietic progenitors. J Immunol 157:1499-1507;1996.

149 Strobl H, Riedl E, Scheinecker C, Bello-Fernandez $\mathrm{C}$, Pickl WF, Rappersberger K, Maj. dic $O$, Knapp W. TGF-beta 1 promotes in vitro development of dendritic cells from CD34+ hemopoietic progenitors. J Immunol 157:1499-1507;1996.
150 Strunk D, Rappersberger K, Egger C, Strobl H, Kromer E, Elbe A, Maurer D, Stingl G. Generation of human dendritic cells/Langerhans cells from circulating CD34+ hematopoietic progenitor cells. Blood 87:1292-1302; 1996.

151 Sun WH, Burkholder JK, Sun J, Culp J, Turner J, Lu XG, Pugh TD, Ershler WB, Yang NS. In vivo cytokine gene transfer by gene gun reduces tumor growth in mice. Proc Natl Acad Sci USA 92:2889-2893;1995.

152 Suzue K, Zhou X, Eisen HN, Young RA. Heat shock fusion proteins as vehicles for antigen delivery into the major histocompatibility complex class I presentation pathway. Proc Natl Acad Sci USA 94:13146-13151. 1997.

153 Syrengelas AD, Chen TT, Levy R. DNA immunization induces protective immunity against B-cell lymphoma. Nat Med 2:1038 1041;1996.

154 Szaboles P, Gallardo HF, Ciocon DH, Sadelain M, Young JW. Retrovirally transduced human dendritic cells express a normal phenotype and potent T-cell stimulatory capacity. Blood 90:2160-2167;1997.

155 Szaboles P, Moore MA, Young JW. Expansion of immunostimulatory dendritic cells among the myeloid progeny of human CD34+ bone marrow precursors cultured with c-kit ligand, granulocyte-macrophage colony-stimulating factor, and TNF-alpha. J Immunol 154:5851-5861;1995.

156 Sznol M, Holmlund J. Antigen-specific agents in development (review). Semin Oncol 24: 173-186;1997.

157 Tahara H, Zeh HJr, Storkus WJ, Pappo I, Watkins SC, Gubler U, Wolf SF, Robbins PD, Lotze MT. Fibroblasts genetically engineered to secrete interleukin 12 can suppress tumor growth and induce antitumor immunity to a murine melanoma in vivo. Cancer Res $54: 182-189 ; 1994$

158 Takahashi H, Takeshita T, Morein B, Putney $\mathrm{S}$, Germain RN, Berzofsky JA. Induction of CD8 + cytotoxic $T$ cells by immunization with purified HIV.1 envelope protein in ISCOMs. Nature 344:873-875; 1990 .

159 Tamura Y, Peng P, Liu K, Daou M, Srivastava $P K$. Immunotherapy of tumors with autologous tumor-derived heat shock protein preparations. Science 278:117-120;1997.

160 Tao MH, Levy R. Idiotype/granulocyte-macrophage colony-stimulating factor fusion protein as a vaccine for B-cell lymphoma. Nature 362:755-758;1993.

161 Tighe H, Corr M, Roman M, Raz E. Gene vaceination: Plasmid DNA is more than just a blueprint. Immunol Today 19:89-97;1998.

162 Tjoa BA, Erickson SJ, Bowes VA, Ragde H, Kenny GM, Cobb OE, Ireton RC, Troychak MJ, Boynton AL, Murphy GP. Follow-up evaluation of prostate cancer patients infused with autologous dendritic cells pulsed with PSMA peptides. Prostate 32:272-278;1997. 
163 Toes RE, Blom RJ, Offringa R, Kast WM, Melief $\mathrm{CJ}$. Enhanced tumor outgrowth after peptide vaccination. Functional deletion of tumor-specific CTL induced by peptide vaccination can lead to the inability to reject tumors. J Immunol 156:3911-3918;1996.

164 Toes RE, Blom RJ, van der Voort E, Offringa R, Melief CJ, Kast WM. Protective antitumor immunity induced by immunization with completely allogeneic tumor cells. Cancer Res $56: 3782-3787 ; 1996$.

165 Toes RE, Hoeben RC, van der Voort EIH, Ressing ME, van der Eb AJ, Melief CJM, Offringa R. Protective anti-tumor immunity induced by vaccination with recombinant adenoviruses encoding multiple tumor-associated cytotoxic $T$ lymphocyte epitopes in a string-of-beads fashion. Proc Natl Acad Sci USA 94:14660-14665;1997.

166 Toes RE, Offringa R, Blom RJ, Melief CJ, Kast WM. Peptide vaccination can lead to enhanced tumor growth through specific $\mathrm{T}$ cell tolerance induction. Proc Natl Acad Sci USA 93:7855-7860;1996.

167 Townsend SE, Allison JP. Tumor rejection after direct costimulation of $\mathrm{CD} 8+\mathrm{T}$ cells by B7-transfected melanoma cells. Science 259 . 368-370;1993.

168 Tuting T, DeLeo AB, Lotze MT, Storkus WJ. Genetically modified bone marrow-derived dendritic cells expressing tumor-associated viral or 'self' antigens induce antitumor immunity in vivo. Eur J Immunol 27:2702$2707 ; 1997$.

169 Tuting T, Gambotto A, Baar J, Davis ID, Storkus WJ, Zavodny PI, Narula S, Tahara H, Robbins PD, Lotze MT. Interferon-alpha gene therapy for cancer: Retroviral transduc tion of fibroblasts and particle-mediated transfection of tumor cells are both effective strategies for gene delivery in murine tumor models. Gene Ther 4:1053-1060;1997.
170 Van den Eynde BJ, van der Bruggen P. T cell defined tumor antigens. Curr Opin Immunol 9:684-693;1997.

171 van Kooten C, Banchereau J. Functional role of CD40 and its ligand (review). Int Arch Allergy Immunol 113:393-399:1997.

172 Walunas TL, Lenschow DJ, Bakker CY, Linsley PS, Freeman GJ, Green JM, Thompson $\mathrm{CB}$, Bluestone JA. CTLA-4 can function as a negative regulator of $T$ cell activation. Immunity $1: 405-413 ; 1994$.

173 Wan Y, Bramson J, Carter R, Graham F, Gauldie J. Dendritic cells transduced with an adenoviral vector encoding a model tumorassociated antigen for tumor vaccination. Hum Gene Ther 8:1355-1363;1997.

174 Wang $G$, Chopra RK, Royal RE, Yang JC, Rosenberg SA, Hwu P. A T cell-independent antitumor response in mice with bone marrow cells retrovirally transduced with an antibody/Fc-gamma chain chimeric receptor gene recognizing a human ovarian cancer antigen. Nat Med 4:168-172;1998.

175 Warnier G, Duffour MT, Uyttenhove $\mathrm{C}_{3} \mathrm{Ga}-$ jewski TF, Lurquin C, Haddada $H$, Perricau$\operatorname{det} \mathrm{M}$, Boon T. Induction of a cytolytic T-cell response in mice with a recombinant adenovirus coding for tumor antigen P815A. Int $J$ Cancer 67:303-310;1996.

176 Weiner GJ, Liu HM, Wooldridge JE, Dahle $\mathrm{CE}$, Krieg $\mathrm{AM}$. Immunostimulatory oligodeoxynucleotides containing the $\mathrm{CpG}$ motif are effective as immune adjuvants in tumor antigen immunization. Proc Natl Acad Sci USA 94:10833-10837;1997.

177 Witmer-Pack MD, Olivier W, Valinsky $J$, Schuler G, Steinman RM. Granulocyte/mac rophage colony-stimulating factor is essential for the viability and function of cultured murine epidermal Langerhans cells. J Exp Med 166:1484-1498;1987.

178 Wu JY, Gardner BH, Kushner NN, Pozzi LA, Kensil CR, Cloutier PA, Coughlin RT, Newman MJ. Accessory cell requirements for saponin adjuvant-induced class I MHC antigen-restricted cytotoxic T-lymphocytes. Cell Immunol 154:393-406;1994.
179 Wu TC, Guamieri FG, Staveley OCKF, Viscidi RP, Levitsky HI, Hedrick L, Cho KR, August JT, Pardoll DM. Engineering an intracellular pathway for major histocompatibility complex class II presentation of antigens. Proc Natl Acad Sci USA 92:11671-11675; 1995.

180 Yang S, Darrow TL, Vervaert CE, Seigler HF. Immunotherapentic potential of tumor antigen-pulsed and unpulsed dendritic cells generated from murine bone marrow. Cell Immunol 179:84-95;1997.

181 Yang YF, Zou JP, Mu J, Wijesuriya R, Ono S, Walunas T, Bluestone J, Fujiwara H, Hamao$\mathrm{ka} \mathrm{T}$. Enhanced induction of antitumor T-cell responses by cytotoxic $T$ lymphocyte-associated molecule- 4 blockade: The effect is manifested only at the restricted tumor-bearing stages. Cancer Res 57:4036-4041;1997.

182 York IA, Rock KL. Antigen processing and presentation by the class I major histocompatibility complex. Annu Rev Immunol 14: 369-396;1996.

183 Zhai Y, Yang IC, Kawakami Y, Spiess P, Wadsworth SC, Cardoza LM, Couture LA, Smith AE, Rosenberg SA. Antigen-specific tomor vaccines. Development and characterization of recombinant adenoviruses encoding MART1 or gp100 for cancer therapy. J Immunol 156:700-710;1996.

184 Zhou LJ, Tedder TF. CD14+ blood monocytes can differentiate into functionally mature CD83+ dendritic cells. Proc Natl Acad Sci USA 93:2588-2592;1996.

185 Zitvogel L, Mayordomo JI, Tjandrawan T, DeLeo AB, Clarke MR, Lotze MT, Storkus WJ. Therapy of murine tumors with tumor peptide-pulsed dendritic cells: Dependence on T cells, B7 costimulation, and Thelper cell 1-associated cytokines. J Exp Med 183:8797;1996. 